\title{
Garner's aldehyde as a versatile intermediate in the synthesis of enantiopure natural products
}

\author{
Mikko Passiniemi and Ari M.P. Koskinen*
}

\section{Review}

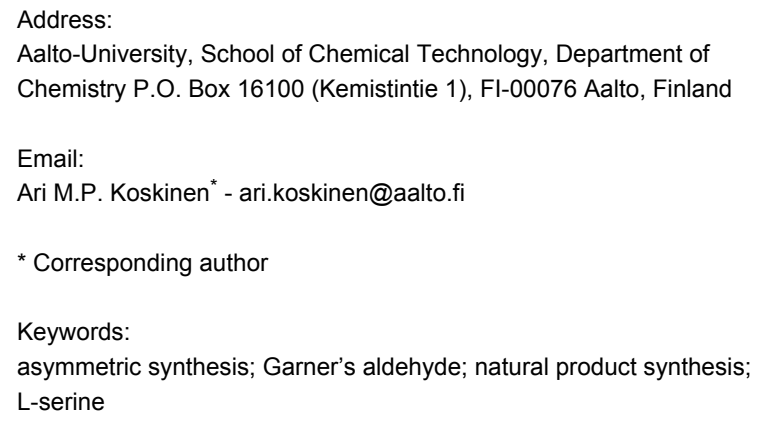

(c) 2013 Passiniemi and Koskinen; licensee Beilstein-Institut. License and terms: see end of document.

\begin{abstract}
Since its introduction to the synthetic community in 1984, Garner's aldehyde has gained substantial attention as a chiral intermediate for the synthesis of numerous amino alcohol derivatives. This review presents some of the most successful carbon chain elongation reactions, namely carbonyl alkylations and olefinations. The literature is reviewed with particular attention on understanding how to avoid the deleterious epimerization of the existing stereocenter in Garner's aldehyde.
\end{abstract}

\section{Introduction}

"The universe is a dissymmetrical whole. I am inclined to think that life, as manifested to us, must be a function of the dissymmetry of the universe and of the consequences it produces. The universe is dissymmetrical; for, if the whole of the bodies which compose the solar system were placed before a glass moving with their individual movements, the image in the glass could not be superimposed on reality. Even the movement of solar life is dissymmetrical. A luminous ray never strikes in a straight line the leaf where vegetable life creates organic matter [...] Life is dominated by dissymmetrical actions. I can even foresee that all living species are primordially, in their structure, in their external forms, functions of cosmic dissymmetry. " [1]

\section{- Louis Pasteur}

These visionary words were written over 100 years ago by Louis Pasteur. Little did he know how great of a challenge underlies these words. Natural products, secondary metabolites produced by living organisms, have their own distinct structures. Some of them have the same chemical structure, but 
differ from each other only by being mirror images (e.g., $(R)(+) /(S)(-)$-limonene and $(S)(+) /(R)(-)$-carvone, Figure 1$)$. This sounds like an insignificant difference, but in reality enantiomers can have a totally different, even contradictory, effect on living organisms. As an example, $(R)$-limonene smells of oranges, whereas the $(S)$-enantiomer has a turpentine-like (with a lemon note) odor. The difference in physiological effects of enantiomers is of utmost importance especially for the pharmaceutical industry, but increasingly also in agrochemicals $[2,3]$ and even in materials sciences, as evidenced by the introduction of chiral organic light emitting diodes [4,5]. In certain cases, one enantiomer may be harmful. This was the case, for example, with the drug thalidomide (Figure 1), the $(R)$-enantiomer of which was sold to pregnant women as a sedative and antiemetic in the 1960s. The $(S)$-enantiomer turned out to be teratogenic.

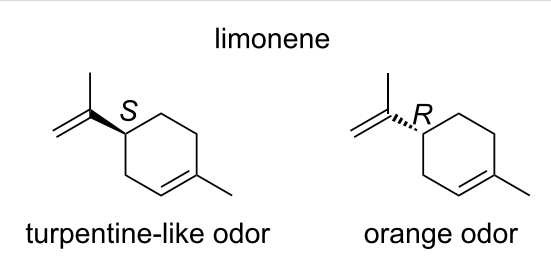

carvone

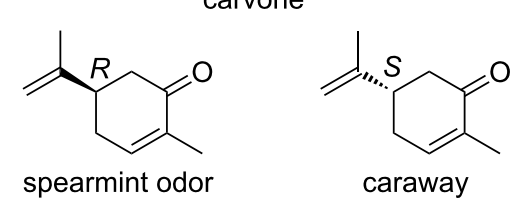

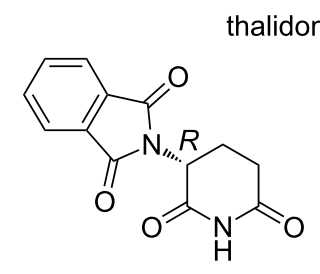

sedative, hypnotic

$$
\text { teratogenic }
$$

Figure 1: Structures of limonene, carvone and thalidomide.

The crucial role of chirality presents a great challenge for synthetic chemists. Asymmetric synthetic methods have emerged and after the development of ample analytical methods over the last few decades, asymmetric synthesis has seen an exponential growth. This has allowed us to tackle even more challenging targets like palytoxin [6-8], vinblastine [9-14], and paclitaxel [15-23]. The field is still far from being mature, and there remains a huge demand for more advanced methods for the introduction of chirality to substrates.
This review presents a general overview of the synthesis and use of Garner's aldehyde in natural product synthesis. Particular attention will be paid on the preservation of chiral information in the addition reaction of nucleophiles to the aldehyde. Models are presented for understanding the factors affecting the stability of the stereocenters, as well as those affecting diastereoselectivity in the generation of the new stereocenter.

\section{Review}

Philip Garner was the first to report a synthesis for 1,1dimethylethyl 4-formyl-2,2-dimethyloxazolidine-3-carboxylate (1, Figure 2), today better known as Garner's aldehyde [24,25]. This configurationally stable aldehyde has shown its power as a chiral building block in the synthesis of various natural products as well as their synthetic intermediates. It is one of the most cited chiral building blocks in recent times and has been used in over 600 publications.

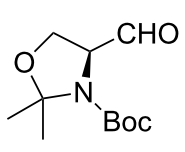

$(S)-1$

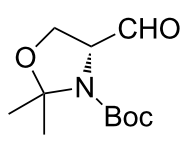

$(R)-1$
Figure 2: Structure of Garner's aldehyde.

\section{Synthesis of Garner's aldehyde}

Garner's aldehyde (1) has been widely used as an intermediate in multistep synthesis. Thus the synthesis of $\mathbf{1}$ has to meet some essential requirements: 1) easy and large scale preparation and 2) configurational and chemical stability of all intermediates.

In his original paper, Garner first protected the amino group with Boc anhydride in dioxane, then esterified the carboxylic acid with iodomethane under basic conditions in dimethylformamide (DMF) and finally formed the dimethyloxazolidine ring of 4 with catalytic $p$-toluenesulfonic acid and 2,2dimethoxypropane (DMP) in refluxing benzene (Scheme 1) [24,25]. Reduction of the methyl ester $\mathbf{4}$ to aldehyde $\mathbf{1}$ was performed with DIBAL-H $(175 \mathrm{~mol} \%)$ at $-78^{\circ} \mathrm{C}$. Garner later reported that they had detected some epimerization of the chiral center (5-7\% loss of ee down to $93-95 \%$ ee) [26]. Another drawback of this route is the use of the toxic and carcinogenic iodomethane in the esterification reaction.

Since the first synthesis of aldehyde $(S)$-1 by Garner there have been many modifications and improvements to the synthesis of the enantiomers $((R)-\mathbf{1}$ and $(S)-\mathbf{1})$. Modifications to the original synthesis have focused either on the reaction sequence (esterification first and then Boc protection) or on the reduction to aldehyde. Other groups have tried to improve the synthesis of the 


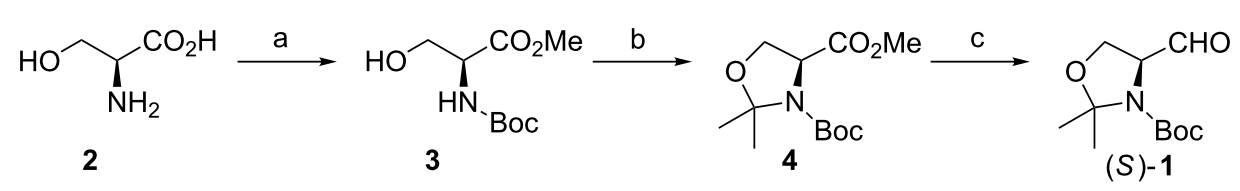

93-95\% ee

Scheme 1: (a) i) $\mathrm{Boc}_{2} \mathrm{O}, 1.0 \mathrm{~N} \mathrm{NaOH}(\mathrm{pH}>10)$, dioxane, $+5^{\circ} \mathrm{C} \rightarrow \mathrm{rt}$; ii) $\mathrm{Mel}, \mathrm{K}_{2} \mathrm{CO}_{3}, \mathrm{DMF}, 0{ }^{\circ} \mathrm{C} \rightarrow \mathrm{rt}\left(86 \%\right.$ over two steps); (b) $\mathrm{Me}{ }_{2} \mathrm{C}(\mathrm{OMe})_{2}$, cat. p-TsOH, benzene, reflux (70-89\%); (c) $1.5 \mathrm{M}$ DIBAL-H, toluene, $-78{ }^{\circ} \mathrm{C}(76 \%)$

aldehyde. McKillop et al. found that the esterification reaction is performed best first with $235 \mathrm{~mol} \%$ of $\mathrm{HCl}$ (formed in situ from the reaction of $\mathrm{AcCl}$ with $\mathrm{MeOH}$ ) in $\mathrm{MeOH}$ [27]. The serine methyl ester hydrochloride salt was then protected with Boc anhydride. The $\mathrm{N}, \mathrm{O}$-acetal was formed using $\mathrm{BF}_{3} \cdot \mathrm{Et}_{2} \mathrm{O}$ and DMP in acetone (Scheme 2). For the reduction they followed Garner's procedure. This method allows an easy access to the fully protected methyl ester $\mathbf{4}$, but the problem of chiral degradation could not be solved (reported rotation -89 vs -91.7 in [26]).

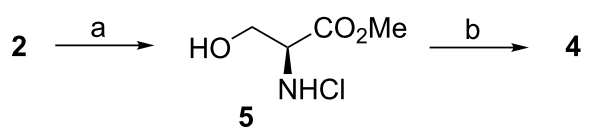

Scheme 2: (a) $\mathrm{AcCl}, \mathrm{MeOH}, 0^{\circ} \mathrm{C} \rightarrow \operatorname{reflux}(99 \%)$; (b) i) $(\mathrm{Boc})_{2} \mathrm{O}, \mathrm{Et}_{3} \mathrm{~N}$ $\mathrm{THF}, 0^{\circ} \mathrm{C} \rightarrow \mathrm{rt} \rightarrow 50{ }^{\circ} \mathrm{C}(89 \%)$; ii) $\mathrm{Me}_{2} \mathrm{C}(\mathrm{OMe})_{2}, \mathrm{BF}_{3} \cdot \mathrm{Et}_{2} \mathrm{O}$, acetone, $\mathrm{rt}$ (91\%).

Dondoni adopted McKillop's procedure for the preparation of $\mathbf{4}$ [28]. In order to reduce the loss of enantiopurity, they decided to follow Roush's protocol [29] for the preparation of the aldehyde, i.e. reduction of $\mathbf{4}$ to alcohol $\mathbf{6}$ and oxidation of this alcohol to $(S)$-1. Moffatt-Swern oxidation provided the final aldehyde $(S)$-1 from the primary alcohol $\mathbf{6}$. In the standard Swern procedure the transformation of the activated alcohol intermediate to the final carbonyl compound (i.e. cleaving off the proton) is done by the addition of $\mathrm{Et}_{3} \mathrm{~N}$ at cold temperatures $\left(-78\right.$ to $\left.-60{ }^{\circ} \mathrm{C}\right)$. According to Roush, the use of triethylamine for this transformation led to partial racemization of $\mathbf{1}(85 \%$ ee). Dondoni noticed that changing the base to the bulkier base $\mathrm{N}, \mathrm{N}$ diisopropylethylamine (Hünig's base, DIPEA) inhibits the epimerization (Scheme 3) [28]. With DIPEA as the base they could isolate the aldehyde $(S)-\mathbf{1}$ with an enantiopurity of 96-98\% ee. The drawback of this route is an additional reaction step, the "overreduction" of the ester $\mathbf{4}$ to alcohol $\mathbf{6}$ and the necessary re-oxidation to aldehyde $\mathbf{1}$.

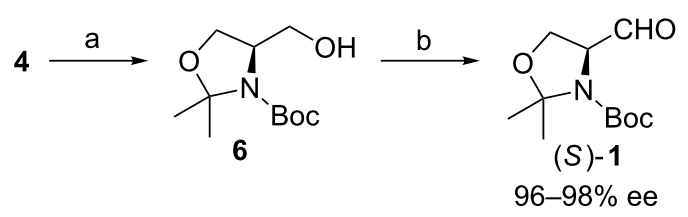

Scheme 3: (a) $\mathrm{LiAlH}_{4}$, THF, rt (93-96\%); (b) (COCl) 2 , DMSO, iPr 2 NEt, $\mathrm{CH}_{2} \mathrm{Cl}_{2},-78^{\circ} \mathrm{C} \rightarrow-55^{\circ} \mathrm{C}(99 \%)$.

As a conclusion of the above results we see that reversing the order of the two first reaction steps has a significant effect on the overall yield (from Garner's 86\% to Dondoni's 94-98\%). Less racemization can be observed with the reduction-oxidation sequence. Of course, other methods for the reduction can be used. The ester can be reduced to alcohol 6 (e.g., with $\left.\mathrm{NaBH}_{4} / \mathrm{LiCl}\right)$ and then oxidized to 1 with non-basic methods (e.g., IBX/DMP [30] or TEMPO/NaOCl [31] to name a few), which will not epimerize the $\alpha$-center.

For our synthesis of $\mathbf{1}$, we adopted a slightly modified sequence [32]. L-Serine (2) is first esterified under traditional Fischer conditions (Scheme 4). The hydrochloride 5 is $N$-protected using (Boc) $)_{2} \mathrm{O}$. The acetonide is then introduced under mild Lewis acidic conditions to give the desired fully protected serine ester 4. This is reduced to the aldehyde 1 with DIBAL-H, while keeping the reaction temperature below $-75^{\circ} \mathrm{C}$. This

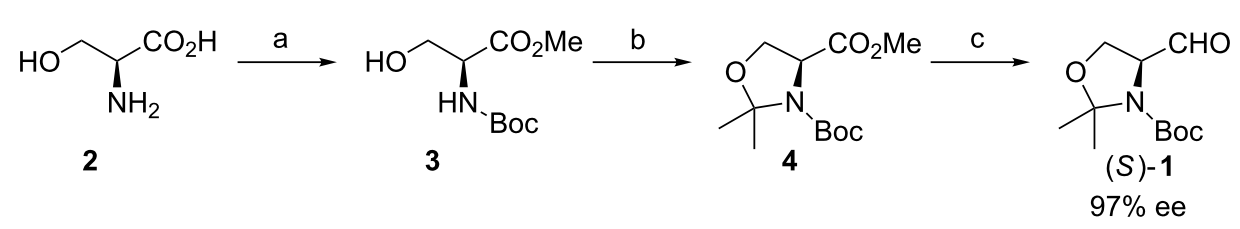

Scheme 4: The Koskinen procedure for the preparation of Garner's aldehyde. (a) i) $\mathrm{AcCl}, \mathrm{MeOH}, 0{ }^{\circ} \mathrm{C} \rightarrow 50{ }^{\circ} \mathrm{C}(99 \%)$; ii) $\left(\mathrm{Boc}_{2} \mathrm{O}, \mathrm{Et}_{3} \mathrm{~N}, \mathrm{CH}_{2} \mathrm{Cl}{ }_{2}\right.$, $0{ }^{\circ} \mathrm{C} \rightarrow$ rt (95-99\%); (b) $\mathrm{Me}_{2} \mathrm{C}(\mathrm{OMe})_{2}, \mathrm{BF}_{3} \cdot \mathrm{Et}_{2} \mathrm{O}, \mathrm{CH}_{2} \mathrm{Cl}_{2}$, rt (86\%, after high vacuum distillation); (c) DIBAL-H, toluene, $-84{ }^{\circ} \mathrm{C}\left(\mathrm{EtOAc} / \mathrm{N}_{2}\right.$ bath) (82-84\%, after high vacuum distillation). 
allowed us to isolate the aldehyde $(S)-1$ in $97 \%$ ee. This reaction sequence was performed in more than $1.0 \mathrm{~mol}$ scale starting from L-serine and the reduction to Garner's aldehyde was performed on a $0.5 \mathrm{~mol}$ scale. DIBAL-H is an efficient reducing agent, but at times causes problems during work-up, especially in larger scale reactions. We, among others, have observed the gelatinous aluminium salts after the addition of an aqueous solution. Due to the formation of insoluble gel-like aluminium salts, the extraction procedure gets more challenging and sometimes a small portion of the substrate remains with the aluminium salts. Another drawback of DIBAL-H is the overreduction to alcohol $\mathbf{6}$. When only small amounts of the overreduced alcohol are present, one high vacuum distillation is enough to purify the crude aldehyde. When present in amounts greater than $10 \%$, two high vacuum distillations are required. Pure aldehyde 1 crystallizes in the freezer and forms semi-transparent white crystals.

Our procedure provides Garner's aldehyde $(S)-1$ in a $66-71 \%$ overall yield. The original Garner procedure provides $(S)-\mathbf{1}$ in $46-58 \%$ and Dondoni's in $75-85 \%$ yield. Dondoni did neither purify his intermediates (from 2 to $(S)-\mathbf{1}$ ) nor the final product. They just reported that all of the products are $>95 \%$ pure based on NMR analysis.
A very recent approach to the synthesis of Garner's aldehyde was published by Burke and Clemens [33]. They reported that $\mathbf{1}$ could be synthesized by asymmetric formylation reaction from Funk's achiral alkene (Scheme 5) [34]. The formylation reaction provided $(R)-\mathbf{1}$ and $(S)-\mathbf{1}$ in acceptable yields $(71 \%$ and $70 \%$, respectively) and excellent enantioselectivities (94\% ee and $97 \%$ ee, respectively). However, this synthesis suffers from many drawbacks. Firstly, the synthesis of the Funk's alkene commences from DL-serine and is a multistep sequence requiring $\mathrm{Pb}(\mathrm{OAc})_{4}$. DL-Serine costs $524 € / \mathrm{kg}$ (Aldrich, June 2013 price) compared to L-serine's $818 € / \mathrm{kg}$ (Aldrich, June 2013). Secondly, both the formylation catalyst and bis(diazaphospholane) ligand are expensive and have to be used in large amounts. Thirdly, the formylation reaction was performed only in a $5 \mathrm{mmol}$ scale and was not optimized for large scale synthesis.

\section{Asymmetric induction with Garner's aldehyde}

Nucleophilic addition to Garner's aldehyde gives an easy access to 2-amino-1,3-dihydroxypropyl substructures. This structural motif can be found in many natural products, such as iminosugars (7 and 9), peptide antibiotics (8), sphingosines and their derivatives (10 and 11, Figure 3). These naturally occurring polyhydroxylated compounds have attracted increasing

\begin{tabular}{|c|c|c|}
\hline \multirow{3}{*}{$(R)-1$} & $\begin{array}{l}2 \% \mathrm{Rh}(\mathrm{CO})_{2} \text { acac } \\
2.5 \%(R, R, S) \text {-BDP }\end{array}$ & $\begin{array}{l}2 \% \operatorname{Rh}(\mathrm{CO})_{2} \text { acac } \\
2.5 \%(S, S, S)-B D P\end{array}$ \\
\hline & $\begin{array}{l}140 \mathrm{psi} \mathrm{H}_{2} / \mathrm{CO} \text {, } \\
55^{\circ} \mathrm{C}, \mathrm{THF}\end{array}$ & $\begin{array}{l}140 \mathrm{psi} \mathrm{H}_{2} / \mathrm{CO} \text {, } \\
55^{\circ} \mathrm{C}, \mathrm{THF}\end{array}$ \\
\hline & regioselectivity $13: 1$ & regioselectivity $20: 1$ \\
\hline
\end{tabular}

$(S)-1$

Scheme 5: Burke's synthesis of Garner's aldehyde. BDP - bis(diazaphospholane).<smiles>OC[C@H]1NCC(O)[C@H](O)[C@H]1O</smiles>

deoxynojirimycin (7)<smiles>OC1CN2CC[C@H]([C@@H](O)C[C@@H]2O)[C@H]1O</smiles>

castanospermine (9)<smiles>Cc1cn([C@@H]2O[C]([C@@H](NC(=O)[C@H](N)[C@H](O)[C@H](O)COC(N)=O)C(=O)O)[C@H](O)[C@H]2O)c(=O)[nH]c1=O</smiles>

polyoxin $\mathrm{J}(8)$<smiles>CCCCCCCCCCCCC/C=C/[C@@H](O)[C@H](N)CO</smiles><smiles>CCCCCCCCCCCCCC[C@H]1OC[C@@H](N)C1O</smiles>

Figure 3: Structures of some iminosugars $(\mathbf{7}, \mathbf{9})$, peptide antibiotics (8) and sphingosine (10) and pachastrissamine (11). 
interest from synthetic chemists, because they are frequently found to be potent inhibitors of many carbohydrate-processing enzymes involved in important biological systems. These unique molecules have tremendous potential as therapeutic agents in a wide range of diseases such as metabolic diseases (lysosomal storage disorders, diabetes), viral infections, tumour metastasis, and neurodegenerative disorders.

Through the addition of a nucleophile to the aldehyde $(S) /(R)-\mathbf{1}$, a new $\mathrm{C}-\mathrm{C}$ bond is formed, hence allowing carbon chain elongation and further functionalization. Nucleophilic addition of an alkyne to $\mathbf{1}$ gives access to propargylic alcohols of the structure A (Scheme 6). This alcohol can be selectively reduced either to cis- (B) or trans-allylic alcohol C. cis-Selective reduction of $\mathbf{A}$ can be achieved with Lindlar's catalyst with $\mathrm{H}_{2}$ under atmospheric pressure. The thermodynamic trans-allylic alcohol $\mathbf{C}$ arises from the reaction of $\mathbf{A}$ with Red-Al. Both isomers $\mathbf{B}$ and $\mathbf{C}$ can also be directly accessed from $\mathbf{1}$ with the corresponding cis- and trans-vinyl nucleophiles. Allylic alcohol $\mathbf{B}$ can be used as an intermediate in the synthesis of various natural products or intermediates thereof. The cis-double bond allows cyclizations to five- or six-membered rings. Five-membered dihydrofuran rings lead to the synthesis of furanomycin $\mathbf{D}[35,36]$, norfuranomycin E [37], and the polyoxin family $\mathbf{F}$ [38]. The sixmembered tetrahydropyridine $\mathbf{G}$ synthesized via this route can be used as an intermediate in the synthesis of iminosugars, e.g., of the deoxynojirimycin family $\mathbf{H}$ [39-43]. The trans-allylic alcohol $\mathbf{C}$ contains already the functional groups of sphingosines and depending on the stereochemistry at $\mathrm{C}_{2}$ and $\mathrm{C}_{3}$, the synthesis of all four isomers can be achieved [44-47]. Isomer $\mathbf{C}$ leads also to the synthesis of deoxynojirimycin family $\mathbf{H}$ [48]. Addition of an allylic nucleophile provides access to homoallylic alcohols I. These can be derivatized to unnatural amino acids, such as $\mathbf{K}$ [49] and $\mathbf{L}$ [50] or to aminosugar derivatives like $\mathbf{M}[29,51]$.

Additions of various nucleophiles to 1 have been summarized by Bols and co-workers in 2001 [52]. We have recently reviewed the literature on the synthesis of 1,2-vicinal amino alcohols [53]. Use of Garner's aldehyde for the synthesis of non-natural amino acids through ethynylglycine has been reviewed [54]. In the following section, significant findings in the use of $\mathbf{1}$ as an electrophile and chiral intermediate will be discussed.

\section{Addition of organometallic reagents to Garner's aldehyde}

The addition of a nucleophile to Garner's aldehyde provides a facile access to 2-amino-1,3-dihydroxypropyl substructures. Through the addition of a carbon nucleophile also a new stereocenter is formed. Depending on the stereofacial selectivity, one can access either the anti-isomer $\mathbf{1 2}$ or $s y n$-isomer $\mathbf{1 3}$ as the<smiles>[R]C1C=CC(C(N)C(=O)O)O1</smiles><smiles>C=CC=[Ru]C</smiles><smiles>[R]C=CC(O)C1COC(C)(C)N1C(=O)OCc1ccccc1</smiles><smiles>OCC1NCC=CC1O</smiles><smiles>[R]C#CC(O)C1COC(C)(C)N1[R6](=O)OC</smiles><smiles>[R]CCCCCCC(=O)OC</smiles><smiles>[R]C=[W]</smiles><smiles>[R]C=CCC1COC(C)(C)N1C(=O)OC(C)(C)C</smiles><smiles>OCC1NCC(O)C(O)C1O</smiles><smiles>[R]C=CC(O)[C@H]1COC(C)(C)N1C(=O)OC(C)(C)C</smiles>
1<smiles>[R]C=CCC</smiles><smiles>[X]C(CC(=O)O)C(N)C(=O)O</smiles><smiles>[R]C=C=C[C@H](C)[C@H](C)I</smiles><smiles>[R]OC1CC(O)OCC1NC(=O)OCc1ccccc1</smiles> 
major product (Scheme 7). The high anti-selectivity can be rationalized with the attack of the nucleophile from the sterically least hindered side (re-side attack). The Felkin-Anh nonchelation transition state model explains this selectivity [55]. The nucleophile attacks not only from the least hindered side (substituent effects), but also from the side where the low-lying $\sigma^{*} \mathrm{C}-\mathrm{N}$ orbital is aligned parallel with the $\pi$ - and $\pi^{*}$-orbital of the carbonyl group, allowing delocalization of electron density from the reaction center toward nitrogen. In cases where synselectivity is observed, the Cram's chelation control model provides an explanation [56,57]. Chelating metal coordinates between the two carbonyls (the aldehyde and the carbamate), thus forcing the nucleophile to attack from the $s i$-side and affecting the selectivity with opposite stereocontrol [58].

In 1988, in pioneering work independently done by Herold [59] and Garner [44] investigated the use of chiral aminoaldehydes as intermediates for the synthesis of nitrogen containing natural products. Both groups realized that the nucleophilic addition of a lithiated alkynyl group to $\mathbf{1}$ in THF was selective, favouring the anti-adduct 14 (Scheme 8). Herold also noticed that the addition of hexamethylphosphorous triamide (HMPT) increased the selectivity from 8:1 (Garner) to $>20: 1$ (anti/syn). HMPT co-ordinates to the Li-cation, thus breaking the lithium clusters. This increases the nucleophilicity of the alkyne and favours the kinetic anti-adduct 14. Through the use of chelating metals $\left(\mathrm{ZnBr}_{2}\right.$ in $\mathrm{Et}_{2} \mathrm{O}$ [59]) Herold noticed a reversal in selectivity favouring the syn-adduct 15 (1:20 anti/syn). Garner used a slightly different method. He formed the nucleophile reductively from pentadecyne with $\mathrm{iBu}_{2} \mathrm{AlH}$ in THF [44]. This vinylalane provided the $s y n$-adduct $\mathbf{1 6}$ in modest stereoselectivity (1:2 anti/syn).

For the addition reaction to be feasible for asymmetric synthesis, the configurational integrity during this step is important.

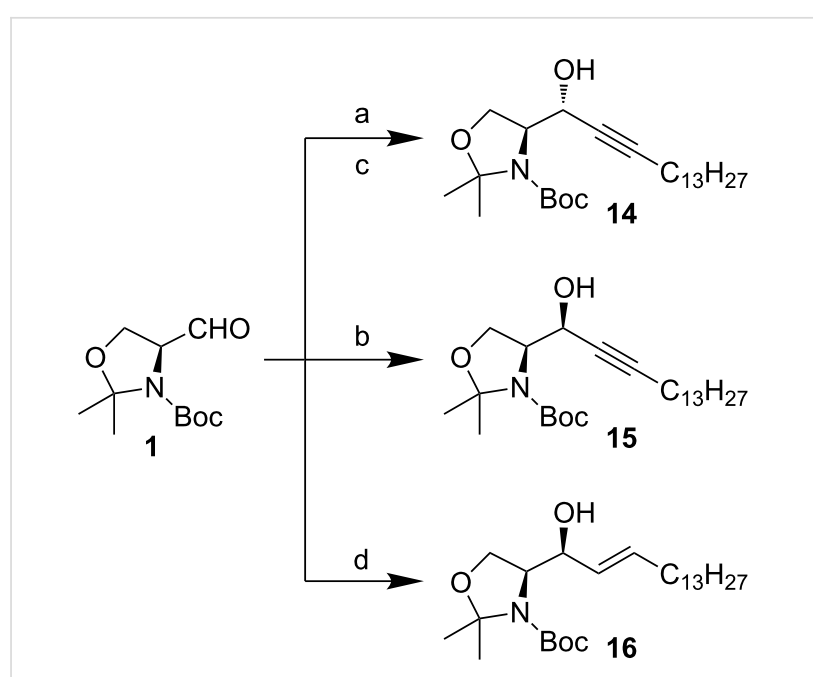

Scheme 8: Herold's method: (a) Lithium 1-pentadecyne, HMPT, THF, $-78{ }^{\circ} \mathrm{C}(71 \%)$; (b) Lithium 1-pentadecyne, $\mathrm{ZnBr}_{2}, \mathrm{Et}_{2} \mathrm{O},-78{ }^{\circ} \mathrm{C} \rightarrow \mathrm{rt}$ (87\%). Garner's method: (c) Lithium 1-pentadecyne, THF, $-23{ }^{\circ} \mathrm{C}$ (83\%); (d) 1-Pentadecyne, DIBAL-H, hexanes/toluene, $-78{ }^{\circ} \mathrm{C}(>80 \%)$.

Garner and many others have demonstrated that there is practically no epimerization of the $\alpha$-carbon center of 1 during the addition reaction [38]. While working on the synthesis of thymine polyoxin $\mathrm{C}$, Garner coupled the lithium salt of ethyl propiolate with $(R)-1$ (Scheme 9) in HMPT/THF at $-78^{\circ} \mathrm{C}$. The reaction was highly anti-selective (13:1 anti/syn) giving adduct $\mathbf{1 7}$ in a good yield (75\%). The propargylic alcohol 17 was converted to the corresponding Mosher esters [60] 18 and 19. A careful NMR analysis indicated that there was less than $2 \%$ cross-contamination.

Since the first results of stereoselective additions by Herold and Garner, much attention has been paid on the factors influencing the stereoselectivity. Coleman and Carpenter studied the nucleophilic addition of vinyl organometallic reagents to $(S)-\mathbf{1}$

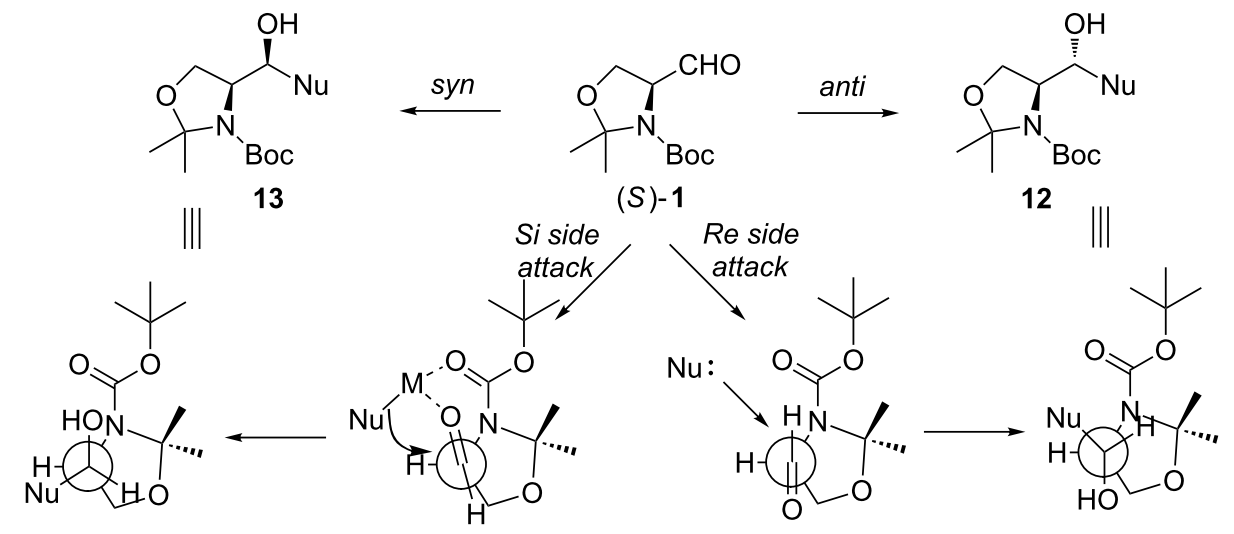




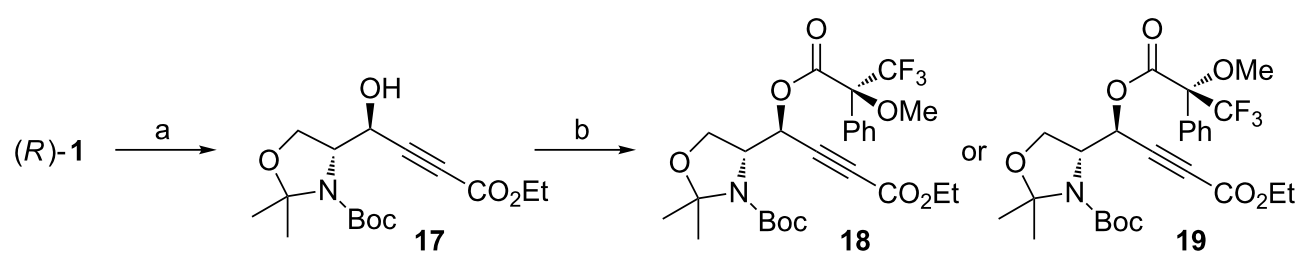

Scheme 9: (a) Ethyl lithiumpropiolate, HMPT, THF, $-78^{\circ} \mathrm{C}$; (b) (S)- or (R)-MTPA, DCC, DMAP, THF, rt (18, 81\%) or (19, 87\%).

(Scheme 10) [61]. They noticed that the addition of vinyllithium in THF provided the anti-adduct $\mathbf{2 0}$ in a moderate $5: 1$ anti/syn-selectivity. By changing the metal to magnesium (vinylMgBr) the selectivity slightly dropped to 3:1 (anti/syn) still favouring adduct 20. Addition of a Lewis acid $\left(\mathrm{TiCl}_{4}\right) \mathrm{did}$ not affect the diastereoselectivity with vinyllithium species. The addition of vinyllithium to $(S)-\mathbf{1}$ in the presence of $100 \mathrm{~mol} \%$ of $\mathrm{TiCl}_{4}$ in THF gave a 5:1 (anti/syn) mixture of adducts $\mathbf{2 0}$ and 21. Tetrahydrofuran coordinates quite strongly to Lewis acids, which increases the electron density at the metal atom. This lowers the metal atom's ability to coordinate to other Lewis bases, such as the carbonyl group. By changing the solvent to a poorer donor ( $\approx$ less Lewis basic), one can alter the electron density brought about by the solvent molecules to the metal atom. With vinyllithium species in the presence of $\mathrm{TiCl}_{4}$ in $\mathrm{Et}_{2} \mathrm{O}$ or toluene, the anti-selectivity dropped to $3: 1$ and 2:1, respectively. Best syn-selectivities were achieved with vinylZnCl in $\mathrm{Et}_{2} \mathrm{O}$ (1:6 anti/syn). Coleman also noticed that the addition of excess $\mathrm{ZnCl}_{2}$ did not increase the $s y n$-selectivity at all. They attributed this to the mono-coordination of the metal to the carbamate instead of the usual "bidentate" chelation control model (as shown in Scheme 10).
Joullié observed that the more reactive Grignard reagents (e.g., $\mathrm{PhMgBr}$ or $\mathrm{MeMgBr}$ ) give rise to kinetic anti-products via the non-chelation pathway [62]. Since these reagents are highly reactive, the reaction takes place before the metal has coordinated to any of the carbonyl groups, thus causing the Felkin-Anh control. When the steric bulk of the nucleophile was increased from $\mathrm{PhMgBr}$ to $\mathrm{iPrMgBr}$ the selectivity reversed from 5:1 anti/syn to 1:6 with iPrMgBr. A distinct solvent effect was also observed (Scheme 11). The selectivity obtained by Joullie for the reaction of 1 with $\mathrm{PhMgBr}$ was reversed for our system [63]. Joullié obtained a 5:1 (anti/syn) selectivity of alcohols 22 and 23 in THF compared to the 2:3 ratio observed in $\mathrm{Et}_{2} \mathrm{O}$. This change in selectivity can be explained by diethyl ether being a less coordinating solvent [64].

Fürstner investigated the use of organorhodium nucleophiles with aldehydes (Scheme 12) [65]. They screened catalysts, ligands and bases in order to find the best conditions for the alkylation reaction. They found $\mathrm{RhCl}_{3} \cdot 3 \mathrm{H}_{2} \mathrm{O}$ together with imidazolium chloride $\mathbf{2 6}$ as the ligand precursor and the base $\mathrm{NaOMe}$ to be the catalyst system of choice. $\mathrm{NaOMe}$ reacts with the ligand precursor $\mathbf{2 6}$ and forms an $N$-heterocyclic carbene.

Scheme 10: Coleman's selectivity studies and their transition state model for the co-ordinated delivery of the vinyl nucleophile.

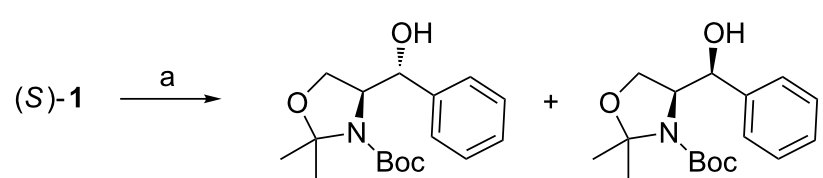

22
23

Scheme 11: (a) $\mathrm{PhMgBr}, \mathrm{THF},-78^{\circ} \mathrm{C} \rightarrow 0{ }^{\circ} \mathrm{C}$ [62] or (a) $\mathrm{PhMgBr}, \mathrm{Et}_{2} \mathrm{O}, 0{ }^{\circ} \mathrm{C}$ [63]. 
<smiles>[R]C(O)C1COC(C)(C)N1[R6](=O)[O-]</smiles>

$\mathrm{R}=\mathrm{Ph} 24$

$\mathrm{R}=\mathrm{CH}_{2}=\mathrm{CHC}_{6} \mathrm{H}_{13} 2$

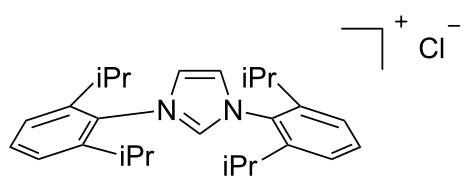

26

Scheme 12: (a) cat. $\mathrm{RhCl}_{3} \cdot 3 \mathrm{H}_{2} \mathrm{O}$, cat. 26, $\mathrm{NaOMe}, \mathrm{Ph}-\mathrm{B}(\mathrm{OH})_{2}$, aq DME, $80{ }^{\circ} \mathrm{C}(\mathbf{2 4}, 71 \%)$; (b) cat. $\mathrm{RhCl}_{3} \cdot 3 \mathrm{H}_{2} \mathrm{O}$, cat. 26, $\mathrm{NaOMe}, \mathrm{C}_{6} \mathrm{H}_{13} \mathrm{CH}=\mathrm{CH}_{2-}$ $\mathrm{B}(\mathrm{OH})_{2}$, aq DME, $55^{\circ} \mathrm{C}(\mathbf{2 5}, \mathbf{7 8} \%)$.

The method was tested also with Garner's aldehyde and two different boronic acid derived nucleophiles $(\mathrm{R}=\mathrm{Ph}$ or 1 -octenyl). High anti-selectivity was observed. With the in situ formed phenyl nucleophile the selectivity was excellent $>30: 1$ (anti/syn) giving $\mathbf{2 4}$ in a good yield (71\%), but with the open chain alkene the selectivity eroded to 4.6:1 (anti/syn) giving 25 in $78 \%$ yield. The $(E)$-octenylboronic acid undergoes protodeborylation at elevated temperatures, so the reaction had to be performed at $55{ }^{\circ} \mathrm{C}$ and with slightly higher catalyst loading ( $5 \%$ instead of the usual $3 \%$ ).

Fujisawa studied the addition of lithiated dithiane to $(S)-\mathbf{1}$ (Scheme 13) [66]. Without additives the reaction in THF provided alcohols 27 and 28 in a 7:3 ratio (anti/syn). Addition of aggregation braking HMPT slightly improved the selectivity (10:3). Almost complete selectivity was achieved when $\mathrm{BF}_{3} \cdot \mathrm{Et}_{2} \mathrm{O}$ (6 equiv) and $\mathrm{CuI}(0.3$ equiv) were used ( $>99: 1$ anti/syn). They reasoned that the high selectivity arose from the use of a monodentate Lewis acid and the highly dissociated anion derived from the organocopper species.

$(S)-1$

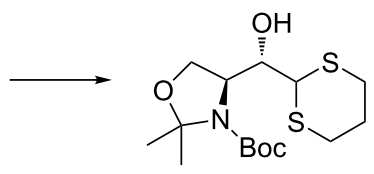

27

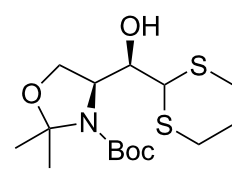

28
Scheme 13: Lithiated dithiane ( 3 equiv), $\mathrm{Cul}$ ( 0.3 equiv), $\mathrm{BF}_{3} \cdot \mathrm{Et}_{2} \mathrm{O}$ (6 equiv), THF, $-50^{\circ} \mathrm{C}, 12 \mathrm{~h}(70 \%)$.

Recently Lam reported interesting results on the stereoselective addition of a lithiated alkynyl species to (S)-1 (Scheme 14) [67]. According to their results, temperature plays a crucial role on the outcome of the reaction. When the reaction was performed at $-15{ }^{\circ} \mathrm{C}$ (1.36 equiv of alkyne and 1.16 equiv of $n$-BuLi), no anti-adduct 29 was detected, instead the $s y n$-adduct $\mathbf{3 0}$ was obtained as the sole stereoisomer. By lowering the temperature to $-40{ }^{\circ} \mathrm{C}$ and keeping the amount of reagents the same, the selectivity was inverted! Only the anti-adduct $\mathbf{2 9}$ was isolated.
This change in selectivity was explained with two different transition states. At lower temperatures $\left(-40{ }^{\circ} \mathrm{C}\right)$ under kinetic control the Felkin-Anh product is predominant. At higher temperatures $\left(-15{ }^{\circ} \mathrm{C}\right)$ the nucleophilic addition occurs via a thermodynamically more stable transition state that resembles the chelation control TS. These results are interesting as this is the first time anyone reports a complete inversion of selectivity just by raising the reaction temperature. Decrease in anti-selectivity has been evidenced by others, when the reaction temperature has been raised by 40 to $100{ }^{\circ} \mathrm{C}$ (e.g., from $-78^{\circ} \mathrm{C}$ to rt), but never a total reverse. If these results are reliable, there has to be a total change in the transition state towards total chelation control and most likely also in the aggregation level of lithiated reagents.<smiles>CCC#CC(O)[C@H]1COC(C)(C)N1C(=O)OC(C)(C)C</smiles>

Scheme 14: Addition reaction reported by Lam et al. (a) 1-Hexyne, $n$-BuLi, THF, $-15^{\circ} \mathrm{C}$ or $-40^{\circ} \mathrm{C}$.

Jurczak has investigated the effect of additives on the selectivity of the nucleophilic addition reaction in toluene [58]. When lithiated 31 was used as the nucleophile, their results were similar to Herold's [59]. With HMPT as an additive they obtained a selectivity of 20:1 favouring the anti-allylic alcohol 32 (Scheme 15). Without additives the selectivity decreased to mere 3:1 (anti/syn). Under the same conditions but by raising the reaction temperature to $\mathrm{rt}$ the selectivity dropped further down to 3:2 (anti/syn). With chelating metals, such as $\mathrm{Mg}, \mathrm{Zn}$ and $\mathrm{Sn}$, the stereofacial preference changed from the re to the $s i$ side attack. The use of tin(IV) chloride as the chelating agent gave the highest syn-selectivities (>1:20 anti:syn), but poor yields. Slightly higher yields were achieved with $\mathrm{ZnCl}_{2}$ giving the $s y n$-adduct 33 in $65 \%$ yield, but with lower selectivities $(1: 10)$. 


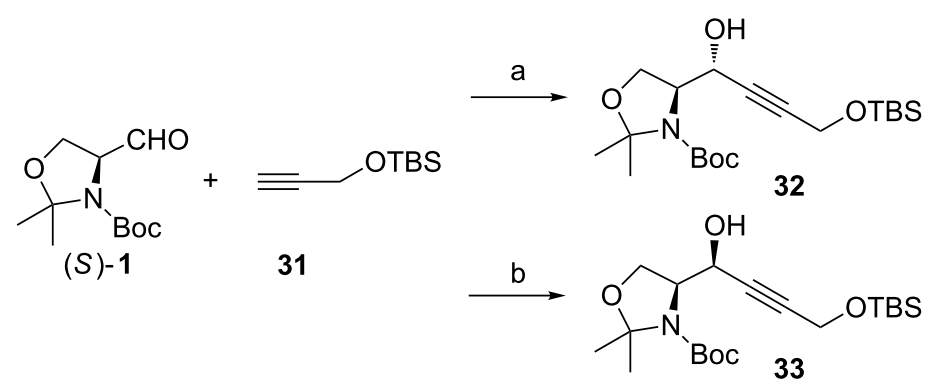

Scheme 15: (a) $n$-BuLi, HMPT, toluene, $-78{ }^{\circ} \mathrm{C} \rightarrow \mathrm{rt}(85 \%)$; (b) $n$-BuLi, $\mathrm{ZnCl}_{2}$, toluene/ $\mathrm{Et}_{2} \mathrm{O},-78^{\circ} \mathrm{C} \rightarrow \mathrm{rt}(65 \%)$.

The additions of propargylic alcohols $\mathbf{3 4}$ and $\mathbf{3 5}$ were also selective (Scheme 16). Mori performed the addition using unprotected alcohol $\mathbf{3 4}$ as nucleophile [68]. The selectivity at $-40{ }^{\circ} \mathrm{C}$ was $4.2: 1$ favouring the anti-adduct 36. Bittman performed similar addition with $\mathbf{3 2}$ as the nucleophile at $-78{ }^{\circ} \mathrm{C}$ [69]. The selectivity was 7.9:1 favouring the anti-adduct 37. In the same year Yadav did the same addition reaction with HMPT which raised the anti-selectivity to $>20: 1$ (anti/syn) [70].

Chisholm has been looking for milder catalytic metal-alkyne nucleophiles for carbonyl 1,2-addition reactions, which wouldn't enolize the labile $\alpha$-protons next to a carbonyl group (Scheme 17) [71]. They found that a $\mathrm{Rh}(\mathrm{I})$-catalyst with a monodentate electron rich phosphine ligand $\mathbf{4 2}$ formed a nucleophilic metal-acetylide with terminal alkynes, such as $\mathbf{4 0}$. The phosphine ligand had to be monodentate; bidentate ligands gave a lot lower yields. Their catalyst system worked very efficiently with many carbonyl electrophiles, also with Garner's aldehyde $(R)$-1. The reaction of $\mathbf{1}$ with $\mathbf{4 0}$ gave $\mathbf{4 1}$ with high selectivity (>20:1 anti/syn) in good yield (74\%). Unfortunately they do not discuss whether the substrate racemizes under these conditions.
Van der Donk has been interested in the synthesis of dehydro amino acids (Scheme 18) [72]. In two of their examples they used copper-acetylide nucleophiles, which led to high syn-selectivities. With propyneCuI the selectivity was 1:16 (anti/syn) providing the propargylic alcohol $\mathbf{4 3}$ in $95 \%$ yield. By changing the nucleophile to TMS-ethyneCuI the $s y n$-selectivity increased to over 1:20, but providing the $s y n$-adduct $\mathbf{4 4}$ in lower yield $(82 \%)$. HPLC analysis showed that no epimerization had occurred. These results support Herold's seminal work published 20 years earlier [59]. Reginato et al. coupled ethyne to Garner's aldehyde $(S)-\mathbf{1}$ under chelation control [73]. Surprisingly, a 1:1 (anti/syn) mixture of adducts $\mathbf{4 5}$ and $\mathbf{4 6}$ was obtained. Hanessian et al. have shown that also electron deficient acetylide nucleophiles can be used in the reaction [74]. After carefully studying the reaction conditions and various additives, they found $\mathrm{ZnBr}_{2}$ to be the best coordinating agent. The diastereoselectivity was good, favouring the syn-adduct $\mathbf{4 7}$ (1:12 anti/syn). The anti-selective addition of a lithiopropiolate to $(R)-1$ was presented by Garner already in 1990 [38].

Soai et al. have examined the use of vinylzinc nucleophiles as alkenylating agents in the synthesis of D-erythro-sphingosine

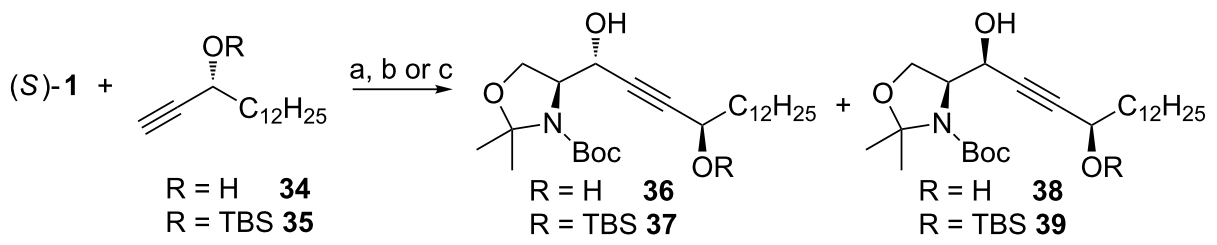

Scheme 16: (a) $n$-BuLi, 34, THF, $-40^{\circ} \mathrm{C}$ [69]; (b) $n$-BuLi, 35, THF, $-78{ }^{\circ} \mathrm{C} \rightarrow \mathrm{rt} \mathrm{(80 \% )} \mathrm{[70];} \mathrm{(c)} n$-BuLi, 35, HMPT, THF, $-78^{\circ} \mathrm{C}(87 \%)$ [71].

$(R)-1+$<smiles>C#Cc1ccccc1</smiles>

40<smiles>[Z11]C(=O)N1[C@H]([C@H](O)C#Cc2ccccc2)COC1(C)C</smiles><smiles>CC(C)(C)P(c1ccccc1-c1ccccc1)C(C)(C)C</smiles> 


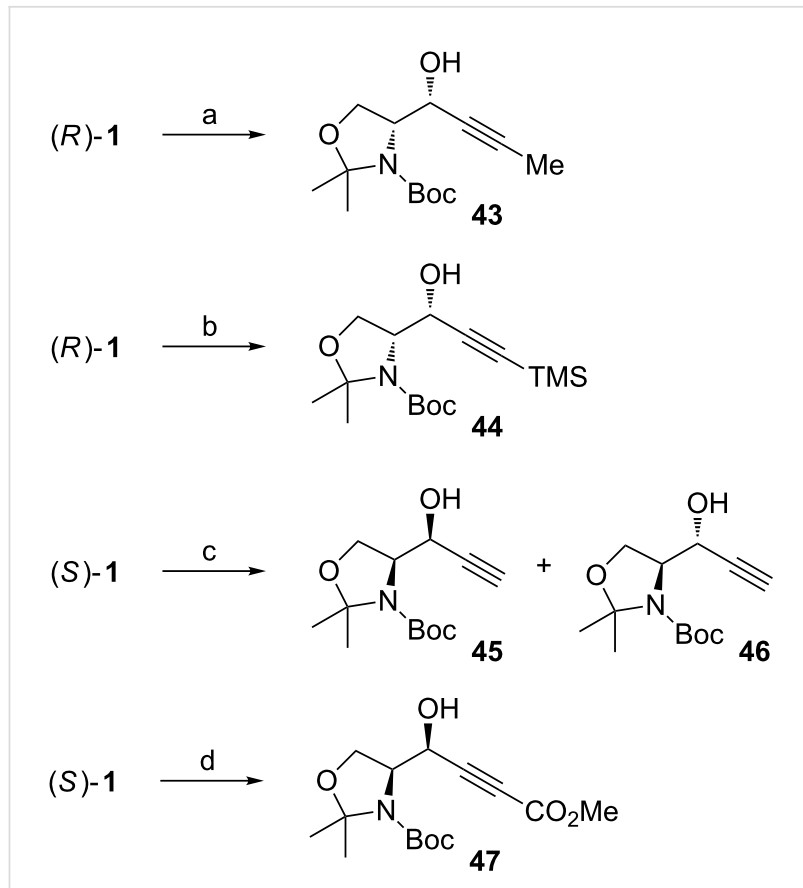

Scheme 18: (a) 1-PropynylMgBr, Cul, THF, $\mathrm{Me}_{2} \mathrm{~S},-78^{\circ} \mathrm{C}(95 \%)$; (b) Ethynyltrimethylsilane, EtMgBr, Cul, THF, $\mathrm{Me}_{2} \mathrm{~S},-78^{\circ} \mathrm{C}(82 \%)$ [72]; (c) EthynylMgCl, $\mathrm{ZnBr}_{2}$, toluene, $-78^{\circ} \mathrm{C}$ [73]; (d) $n$-BuLi, methyl propiolate, $\mathrm{Et}_{2} \mathrm{O},-78{ }^{\circ} \mathrm{C} \rightarrow 0{ }^{\circ} \mathrm{C}$, then $(S)-1$ at $-20^{\circ} \mathrm{C}(62 \%)$ [74].

(Scheme 19) [45]. Treatment of $(S)$-1 with pentadecenyl(ethyl)zinc (48) in the presence of catalytic $(R)$-diphenyl(1methylpyrrolidin-2-yl)methanol (50, $(R)$-DPMPM) [75] in toluene at $0{ }^{\circ} \mathrm{C}$ gave adducts 49 and 16 in a $4: 1$ ratio (anti/syn). By changing the chiral ligand to $(S)$-DPMPM 51 the selectivity dropped to 2:1 (anti/syn). When the addition reaction was performed in the presence of achiral $N, N$-dibutylaminoethanol 52 they obtained the highest selectivities (7.3:1 anti/syn). Despite performing the reaction seemingly under chelation control, the selectivity follows the Felkin-Anh transition state model. This selectivity arises from the use of metal coordinating $\mathrm{N}, \mathrm{O}$-ligands. These ligands affect both the reactivity of the metalated nucleophiles and also the metal's capability of coordination.
Montgomery studied the nickel-catalyzed reductive additions of $\alpha$-aminoaldehydes with silylalkynes (Scheme 20) [76]. The reduction of TMS-alkyne $\mathbf{5 3}$ was performed with a trialkylsilane and a $\mathrm{Ni}(\mathrm{COD})_{2}$ catalyst ligated with an in situ formed $\mathrm{N}$-heterocyclic carbene. In all cases studied, they found both the anti/syn- and the $Z / E$-selectivity to be high $(>20: 1)$, but the chemical yield was varying. Highest yields (78-80\%) were achieved with short alkyl chains $(\mathrm{R}=\mathrm{Me})$ or when $\mathrm{R}=$ phenyl. When the alkyl chain was lengthened $\left(\mathrm{R}=\mathrm{C}_{13} \mathrm{H}_{27}\right)$, while aiming for the synthesis of D-erythro-sphingosine, the yield drastically dropped to $18 \%$. By changing the reaction conditions (2 equiv of $(S)-1$ with $1 \%$ water in THF) the yield increased to acceptable levels $(65 \%)$ while the selectivity remained practically the same. They also tested the reaction with other serinal derivatives, but the best results were achieved with $(S)$-1.

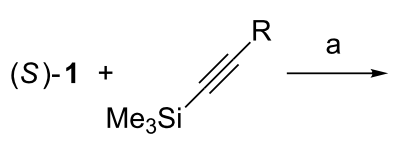

53

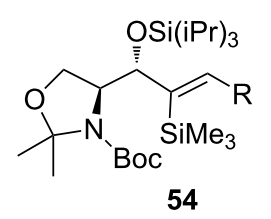

54
Scheme 20: (a) (iPr) $)_{3} \mathrm{SiH}$, cat. $\mathrm{Ni}(\mathrm{COD})_{2}$, dimesityleneimidazolium. $\mathrm{HCl}, t-\mathrm{BuOK}, \mathrm{THF}, \mathrm{rt}$.

Alkynes can be converted to $(E)$-vinyl nucleophiles through hydrozirconation. In view of the relatively low electronegativity (1.2-1.4) of $\mathrm{Zr}$, which is roughly comparable with that of $\mathrm{Mg}$ and somewhat lower than that of $\mathrm{Al}$, the low reactivity of organylzirconocene chlorides towards carbonyl compounds is puzzling. It is likely that the presence of two sterically demanding cyclopentadienyl $(\mathrm{Cp})$ groups is at least partially responsible for their low reactivity. Suzuki noticed that Lewis acids promote $\mathrm{C}-\mathrm{C}$-bond forming reactions of organylzirconocene nucleophiles (Scheme 21) [77]. They used $\mathrm{AgAsF}_{6}$ as the Lewis acid promoter and found that also Garner's aldehyde reacts under these conditions with 1-hexenylzirconocene. The

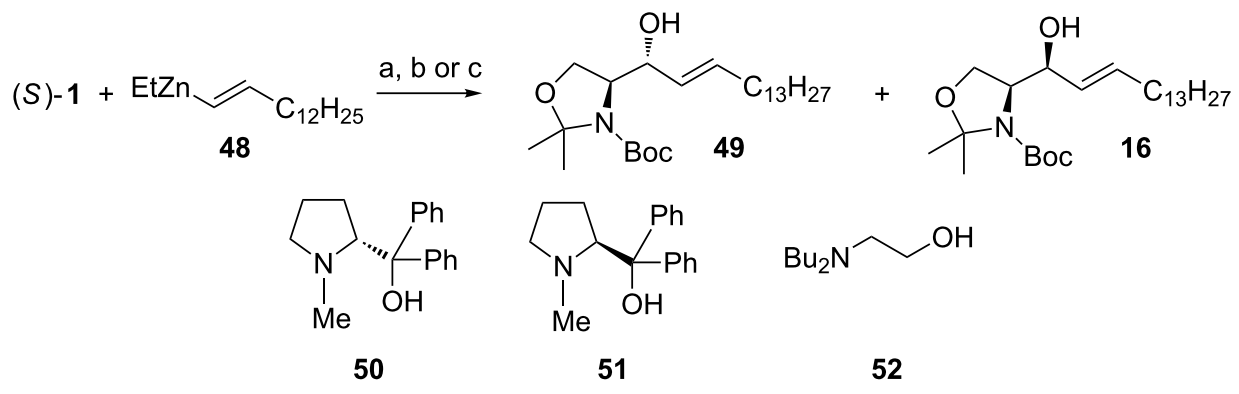

Scheme 19: (a) cat. 50 , toluene, $0{ }^{\circ} \mathrm{C}(52 \%)$; (b) cat. 51 , toluene, $0{ }^{\circ} \mathrm{C}(51 \%)$; (c) cat. $\mathbf{5 2}$, toluene, $0{ }^{\circ} \mathrm{C}(50 \%)$. 
(S)-1+<smiles>C#CCP</smiles>

a

(S)-1<smiles>C#CCCCCCC</smiles>

58

(S)-1<smiles>C#CCO[SbH2]C</smiles>

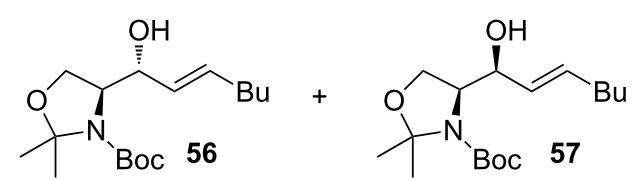

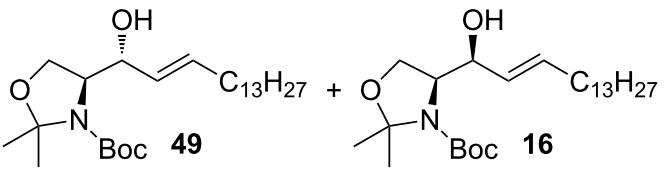<smiles>CC(C)(C)OC(=O)c1ccccc1</smiles>

Scheme 21: (a) $\mathrm{Cp}_{2} \mathrm{Zr}(\mathrm{H}) \mathrm{Cl}$, cat. $\mathrm{AgAsF}_{6}, \mathrm{CH}_{2} \mathrm{Cl}_{2}$, rt; (b) $\mathrm{Cp}_{2} \mathrm{Zr}(\mathrm{H}) \mathrm{Cl}$, 1-pentadecyne, cat. $\mathrm{ZnBr}_{2}$ in THF for anti-selective or $\mathrm{ZnEt}_{2}$ in $\mathrm{CH}_{2} \mathrm{Cl}_{2}$ for synselective reaction. (c) $\mathrm{Cp}_{2} \mathrm{Zr}(\mathrm{H}) \mathrm{Cl}, \mathrm{Et}_{2} \mathrm{Zn}$, in $\mathrm{CH}_{2} \mathrm{Cl}_{2}$, for syn-selective reaction or in $\mathrm{THF}$ for anti-selective reaction.

reaction gave a good yield of the addition products $\mathbf{5 6}$ and $\mathbf{5 7}$ (70\% combined yield), but no diastereoselectivity was observed. Peter Wipf has done pioneering work on the hydrozirconation-transmetallation sequence [78,79]. Murakami used this information when investigating the reaction of transmetallated 1-(E)-pentadecenylzirconocene chloride with $(S)$-1 $[46,47]$. When the reaction was performed in THF at $0{ }^{\circ} \mathrm{C}$ and $50 \mathrm{~mol} \%$ of $\mathrm{ZnBr}_{2}$ was added, the reaction gave the anti-adduct 49 as the major diastereomer (12:1 anti/syn). When the amount of $\mathrm{ZnBr}_{2}$ was lowered to half $(25 \mathrm{~mol} \%$ ) the selectivity rose to 20:1 (anti/syn). The selectivity was reversed to 1:15 (anti/syn) favouring the syn-adduct 16, when the solvent was changed to less coordinating $\mathrm{CH}_{2} \mathrm{Cl}_{2}$ and the 1-(E)-pentadecenylzirconocene chloride was transmetallated with $\mathrm{Et}_{2} \mathrm{Zn}$ prior to the addition of $(S)$-1. Interestingly, when the addition was performed in THF in the presence of the transmetallated 1-(E)pentadecenyl(ethyl)zinc, the selectivity was inverted, and the anti-adduct 49 was favoured (12:1 anti/syn).

We have also been interested in the use of hydrozirconation-transmetallation process while working on the synthesis of galactonojirimycin (Scheme 21) [48]. We used the TBSprotected propargyl alcohol $\mathbf{3 1}$ as the nucleophile, which had been investigated by Negishi for the hydrozirconation-trans- metallation process [80]. Our findings were in agreement with the results of Murakami. High syn-selectivity ( $>1: 20$ anti/syn) was achieved in $\mathrm{CH}_{2} \mathrm{Cl}_{2}$ with $\mathrm{Et}_{2} \mathrm{Zn}$ as the transmetallating agent. The reaction could also be performed in toluene, but the hydrozirconation had to be done in $\mathrm{CH}_{2} \mathrm{Cl}_{2}$ due to the low solubility of the Schwartz's reagent in toluene. After formation of the hydrozirconated species, the solvent could be changed to toluene. This reaction gave a slightly lower yield in toluene, but identical selectivity favouring adduct $\mathbf{6 0}$. By changing the solvent to THF the stereochemical outcome was reversed. The anti-adduct 59 could be isolated in a $>20: 1$ anti/syn ratio. Unfortunately, the chemical yield was substantially lower (20\%) and many byproducts were observed. Most importantly, these reaction conditions did not affect the chiral integrity of (S)-1. In a recent synthesis of (-)-1-deoxyaltronojirimycin we tried to synthesize the anti-adduct 59 [43]. Poor yield for vinylic addition forced us to look for alternative methods (Scheme 22). Despite the literature precedence of anti-selective reactions, we were unable to selectively synthesize this adduct in a good yield. We then turned to the lithiated nucleophile $\mathbf{3 1}$. In THF at $-78{ }^{\circ} \mathrm{C}$ high diastereoselectivity (15:1 anti/syn) was obtained. Unfortunately, direct reduction of $\mathbf{3 2}$ to $\mathbf{5 9}$ produced allene as a byproduct, which forced us to modify the synthetic route.

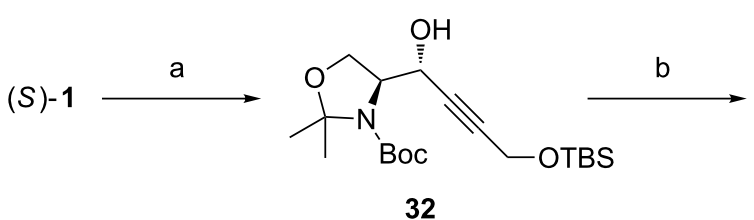

32<smiles>CCCCOCC=CC(O)[C@@H]1COC(C)(C)N1C(=O)c1ccccc1</smiles>

59<smiles>C=C=C[C@H](O)[C@@H]1COC(C)(C)N1[13C](=O)OC(=O)OCc1ccccc1</smiles>

byproduct 
We have also successfully used ( $Z$ )-vinyl nucleophiles created from the vinyl iodide $\mathbf{6 1}$ in the stereoselective synthesis of pachastrissamine (11) [81,82] and norfuranomycin [37] (Scheme 23). After halogen-metal exchange with $n$-BuLi, the newly formed nucleophile reacts with $(S)-\mathbf{1}$. When HMPT or dimethylpropyleneurea (DMPU) were used, high anti-selectivities were achieved (up to 17:1 anti/syn). Without additives the reaction gave a 4:1 anti/syn mixture of allylic alcohols $\mathbf{6 2}$ and
63. Chelating metals gave rise to the $s y n$-adduct 63. When we used $\mathrm{ZnCl}_{2}$ dissolved in $\mathrm{Et}_{2} \mathrm{O}$ as the chelating agent, the synselectivity rose to about 1:6 favouring adduct $\mathbf{6 3}$. These results are in agreement with the findings of Jurczak [68].

The alkylation results are summarized in Table 1, and overall one can conclude that Garner's aldehyde $\mathbf{1}$ is a highly versatile intermediate for organic synthesis. The selectivity of the 1,2-<smiles>CC(C)(C)OC(=O)c1ccccc1</smiles>

Scheme 23: (a) $61, n$-BuLi, DMPU, toluene, $-78{ }^{\circ} \mathrm{C}$, then $(S)-1$, toluene, $-95^{\circ} \mathrm{C}(57 \%)$; (b) $61, n-\mathrm{BuLi}, \mathrm{ZnCl} 2$, toluene, $-78{ }^{\circ} \mathrm{C}$, then $(S)-1$, toluene, $-95^{\circ} \mathrm{C}(72 \%)$.

Table 1: Selectivities and yield for additions of various nucleophiles to Garner's aldehyde 1.

\begin{tabular}{|c|c|c|c|c|c|c|c|}
\hline Entry & Nucleophile & Additive & Solvent & $T\left({ }^{\circ} \mathrm{C}\right)$ & antilsyn & Yield (\%) & Ref \\
\hline 1 & & HMPT & THF & -78 & $>20: 1$ & 71 & [59] \\
\hline 2 & & - & THF & -23 & $8: 1$ & 83 & [50] \\
\hline 3 & & $\mathrm{ZnBr}_{2}$ & $\mathrm{Et}_{2} \mathrm{O}$ & $-78 \rightarrow \mathrm{rt}$ & $1: 15$ & 87 & [59] \\
\hline 4 & & HMPT & toluene & $-78 \rightarrow 0$ & $20: 1$ & 85 & [58] \\
\hline 5 & & - & THF & -78 & $15: 1$ & 80 & [43] \\
\hline 6 & & - & toluene & $-78 \rightarrow \mathrm{rt}$ & $3: 1$ & 80 & [58] \\
\hline 7 & & $\mathrm{ZnCl}_{2}$ & toluene/ $\mathrm{Et}_{2} \mathrm{O}$ & $-78 \rightarrow \mathrm{rt}$ & $1: 10$ & 65 & [58] \\
\hline 8 & & Cul & $\mathrm{THF} / \mathrm{Me}_{2} \mathrm{~S}$ & -78 & $1: 16$ & 95 & [72] \\
\hline 9 & & $\mathrm{ZnBr}_{2}$ & THF/toluene & -78 & $1: 1$ & - & [73] \\
\hline 10 & & HMPT & THF & -78 & $13: 1$ & 75 & [38] \\
\hline 11 & & - & $\mathrm{Et}_{2} \mathrm{O}$ & $-78 \rightarrow 0$ & $1: 12$ & 62 & [74] \\
\hline 12 & & - & THF & 40 & $20: 1$ & 74 & [71] \\
\hline
\end{tabular}




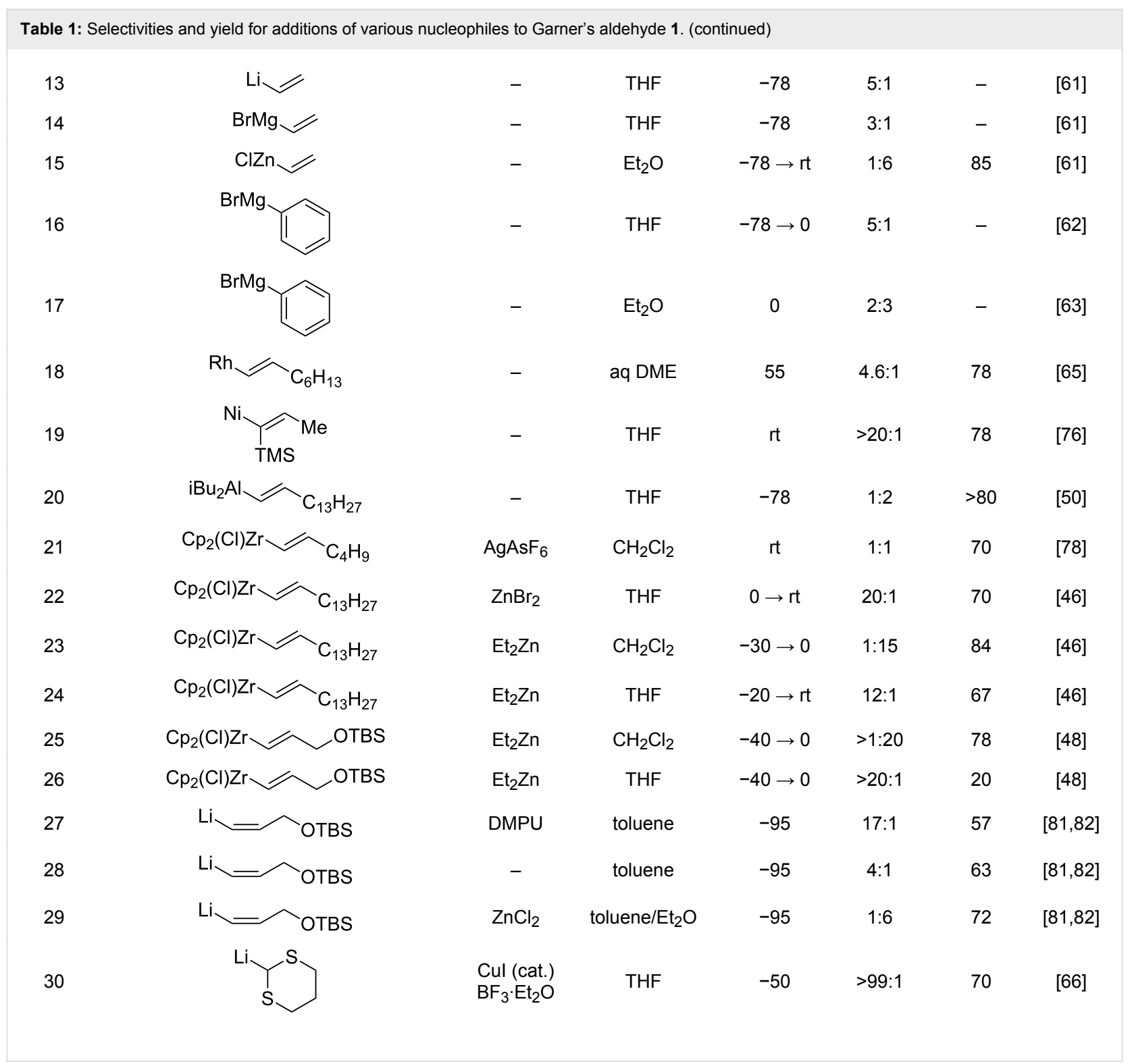

asymmetric induction can be controlled, either by choice of the nucleophilic reagent, chelating or aggregates breaking additives, solvent and sometimes also by the reaction temperature. Less coordinating metals and more reactive nucleophiles tend to give Felkin-Anh products (Table 1, entries 2, 5, 6, 12-14, 16, 18, 19 and 28). Smaller alkyne nucleophiles seem to give a roughly $8: 1$ anti/syn-selectivity. The larger organovinyl reagents give slightly lower anti-selectivities of about 3:1 to 5:1. Highest selectivities are reached with transition metals, such as $\mathrm{Rh}$ and Ni (Table 1, entries 12, 18 and 19). The anti-selectivity can be enhanced either by the addition of aggregation breaking additives, such as HMPT and DMPU (Table 1, entries 1, 4, 10 and 27 ) or by the use of strongly Lewis basic solvents, like THF (Table 1, entries 2, 5, 13, 14, 16 and 24). Using aggregate breaking additives increases the anti-selectivities from 4-5:1 to
$>20: 1$. The increase of nucleophilicity diminishes the metal cations capability or chances to coordinate to the carbonyl groups. This promotes the attack of the nucleophile from the least hindered re side.

Chelation control can also be achieved by the proper choice of solvents. Even changing from THF to $\mathrm{Et}_{2} \mathrm{O}$ is often enough to inverse the selectivity (Table 1, entries 10,11, 16 and 17). Less coordinating solvents, such as toluene or $\mathrm{CH}_{2} \mathrm{Cl}_{2}$ can also affect the selectivity. A greater effect on the selectivity can be reached by the addition of Lewis acids. Usually $\mathrm{Zn}$ (II)-salts give fair to good syn-selectivities (Table 1, entries 3, 7, 23, 25 and 29), if the solvent is non-coordinating $\left(\mathrm{Et}_{2} \mathrm{O}\right.$, toluene or $\left.\mathrm{CH}_{2} \mathrm{Cl}_{2}\right)$. $\mathrm{Zn}(\mathrm{II})$-salts do not necessarily give $s y n$-selectivities, especially if they are too reactive to chelate to the substrate (Table 1, 
entry 9). Vinylalanes give varying results, preferring either antior syn-selectivity (Table 1, entry 20).

\section{Olefination of Garner's aldehyde}

Olefination of 1 provides an easy access to chiral 2-aminohomoallylic alcohols A (Scheme 24). The intermediate can be derivatized further, thus providing a route for greater molecular diversity. Diastereoselective dihydroxylation of $\mathbf{A}$ with $\mathrm{OsO}_{4}$ leads to triols $\mathbf{B}$, which have been utilized in the syntheses of calyculins family [83,84], D-ribo-phytosphingosine [85], and radicamine [86,87]. If the R-group in $\mathbf{A}$ is an ester, diastereoselective Michael addition leads to structures $\mathbf{C}$ [88-92]. Kainic acid was synthesized using such conjugate addition [93], and a recent synthesis of lucentamycin A was achieved using this strategy [94]. Epoxidation of A leads to a highly functional intermediate $\mathbf{C}$, which has been used in the synthesis of manzacidin B [95].
Among the plethora of olefination reactions, the Wittig [96,97] and Horner-Wadsworth-Emmons [98-100] reactions are most commonly used for the introduction of a double bond to Garner's aldehyde 1. Two things need to be considered before performing the olefination reactions: 1) epimerization of the stereocenter in the aldehyde (i.e. basicity vs nucleophilicity of the olefinating reagents) and 2) E/Z-selectivity of the reaction.

Moriwake et al. noticed in their synthesis of vinylglycinol 64 that the reaction of methyltriphenylphosphonium bromide with $\mathrm{KH}$ as the base provided $\mathbf{6 2}$ in fairly good yield, but with complete racemization of the product (Scheme 25) [101]. This racemization could be overcome by performing the olefination with $\mathrm{AlMe}_{3}-\mathrm{Zn}-\mathrm{CH}_{2} \mathrm{I}_{2}$ in benzene under non-basic conditions. While looking for non-racemizing conditions for the same reaction, Beaulieu et al. found that the ylide formed from methyltriphenylphosphonium bromide and $n$-BuLi in THF gave 62 in

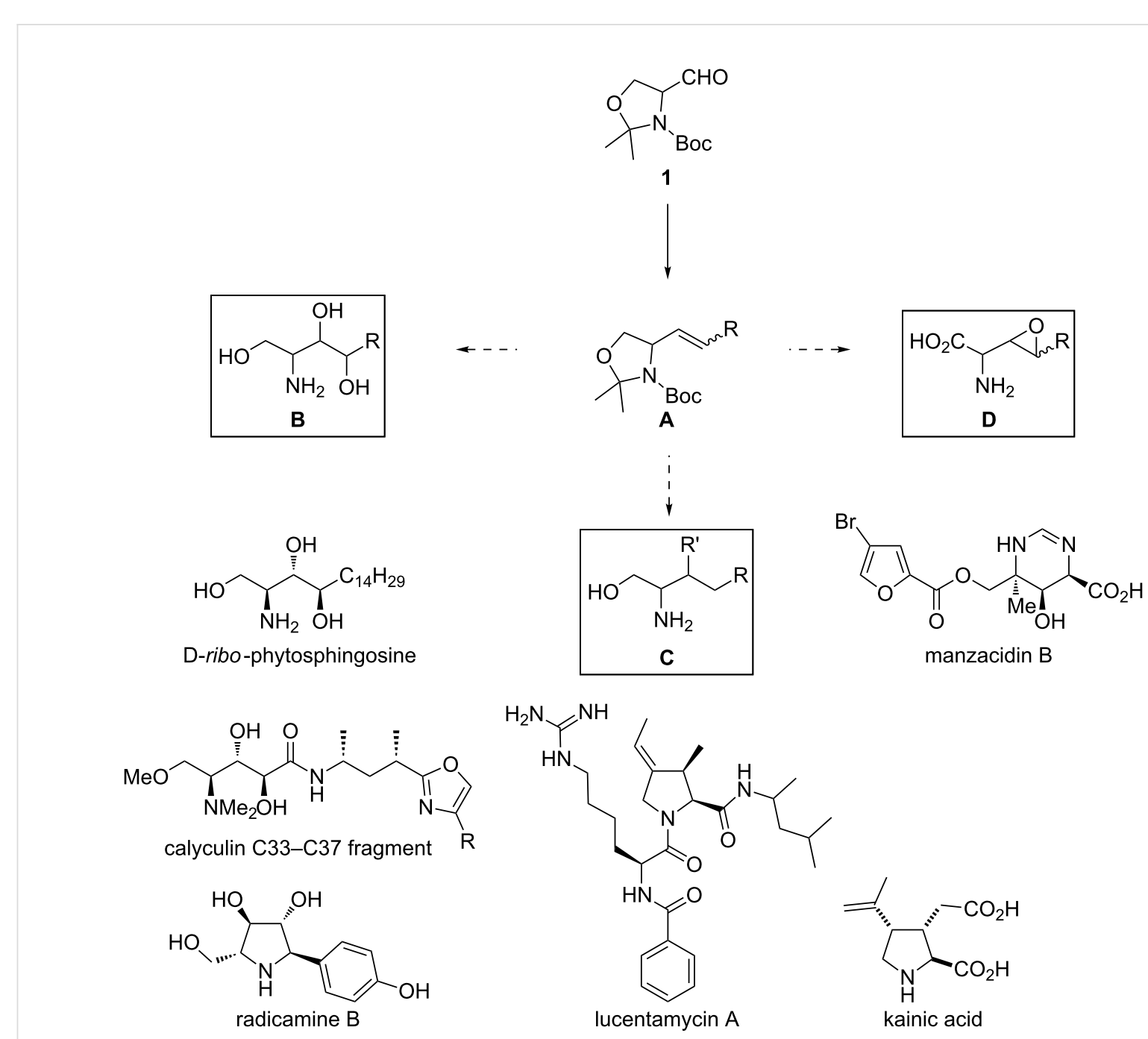


$69 \%$ ee, but in low yield (27\%) [102]. With a different unstabilized ylide 65 , the enantiopurity of the Wittig product increased to $>95 \%$ ee. The erosion of enantiopurity was attributed to the ylide $\left(\mathrm{Ph}_{3} \mathrm{P}=\mathrm{CH}_{2}\right)$ being too basic. It is well known that phosphonium ylides form stable complexes with alkali metals during the dehydrohalogenation of the phosphonium salt [103]. These complexes react with carbonyl compounds differently. Addition reactions of other ylides to 1 , proceeded with little or no racemization of 1 . The $E / Z$-ratio of the reaction was $1: 13$ favouring the $Z$-adduct 66 . In comparison to Beaulieu's results, McKillop [27] noticed that with KHMDS as the base, there was no epimerization at all! To prepare "salt-free" ylides, it is necessary to remove lithium halide from the reaction solution. On the other hand KHMDS is a convenient base for the preparation of "salt-free" ylides.

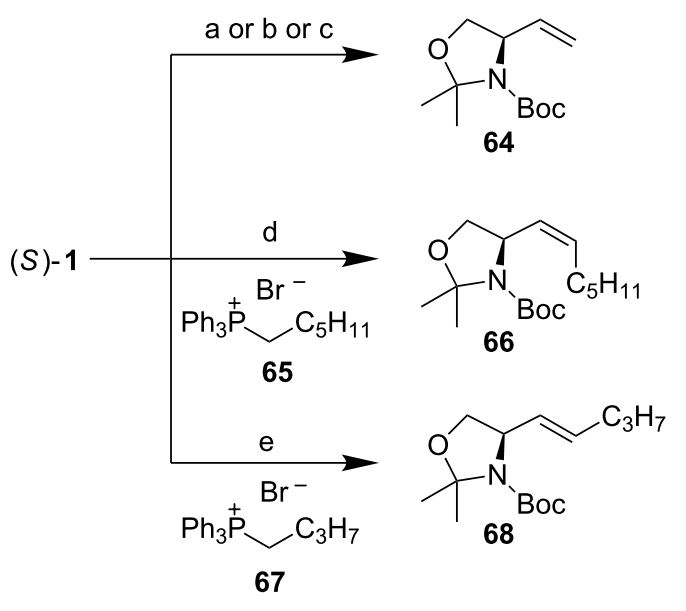

Scheme 25: (a) $\mathrm{Ph}_{3}(\mathrm{Me}) \mathrm{PBr}, \mathrm{KH}$, benzene $\left(66 \%\right.$, rac-64) or (b) $\mathrm{AlMe}_{3}$ $\mathrm{Zn}, \mathrm{CH}_{2} \mathrm{I}_{2}$, THF (76\%) [101]; (c) $\mathrm{Ph}_{3}(\mathrm{Me}) \mathrm{PBr}, n-\mathrm{BuLi}, \mathrm{THF},-75^{\circ} \mathrm{C}$, then (S)-1 (27\%,69\% ee) [102]; (d) 65, $n$-BuLi, THF, $-75^{\circ} \mathrm{C}$, then (S)-1 (78\%, 1:13 E/Z, >95\% ee); (e) 67, KHMDS, THF, $-78^{\circ} \mathrm{C}$, then (S)-1, quenching with $\mathrm{MeOH}(70 \%,>10: 1 \mathrm{E} / Z)$ [104].

High $Z$-selectivity is a typical outcome with unstabilized ylides. Kim has investigated means of reversing the $E / Z$-selectivity to favour the $E$-isomer [104]. They noticed that olefination under the usual Wittig conditions provided high $Z$-selectivity (1:15 $E / Z$ ). When the reaction was quenched with $\mathrm{MeOH}$ at $-78^{\circ} \mathrm{C}$, the $E / Z$-ratio was reversed to $>10: 1$ favouring adduct $\mathbf{6 8}$ [105]

$\alpha, \beta$-Unsaturated esters can be synthesized from stabilized ylides. Reaction of $\mathbf{1}$ with ylide $\mathbf{6 9}$ is $E$-selective. Depending on the solvent, the $E / Z$-ratio can vary from 3:1 (in $\mathrm{MeOH}$ ) [106] to 100:0 (THF [107] or benzene [108]). Since stabilized ylides are less reactive compared to their non-stabilized counterparts, they tend to epimerize the existing chiral center of 1 a lot less, if at all ( $\mathrm{p} K_{\mathrm{aH}}$ value of $\mathbf{6 9}$ in DMSO is 8.5 compared to the $\mathrm{p} K_{\mathrm{a}}$ value of $\mathrm{Ph}_{3}(\mathrm{Me}) \mathrm{PBr}$, which is 22.5) [109].
Another method to prepare $\alpha, \beta$-unsaturated esters is the Horner-Wadsworth-Emmons reaction (HWE). The HWE reaction has many advantages over the Wittig olefination. The phosphonate anions tend to be more nucleophilic (less basic) than the corresponding phosphorous ylides. The byproducts, dialkyl phosphates are water soluble and hence easier to remove from the product compared to, e.g., triphenylphospine oxide. As with the Wittig reaction, the HWE reaction can also promote the epimerization of the $\alpha$-proton ( $\mathrm{p} K_{\mathrm{a}}$ of triethoxyphosphonoacetate in DMSO is 18.6) [109]. We have experienced this tendency especially with $\alpha$-amino ketophosphonates [110], but there is also evidence that aldehyde $\mathbf{1}$ can lose some of its chiral integrity in the HWE reaction. For base sensitive substrates the use of metal salts ( $\mathrm{LiCl}$ or $\mathrm{NaI}$ ) and an amine base (DBU or DIPEA) has proven to be effective in avoiding epimerization [111]. The use of $\mathrm{Ba}(\mathrm{OH})_{2}$ in aq THF has also been advocated to prevent epimerization [112], and recently Myers has reported the superiority of lithium hexafluoroisopropoxide as a mild base for HWE olefinations of epimerizable aldehydes [113]. Jako et al. showed that $E$-enoate $\mathbf{7 2}$ can be synthesized from Garner's aldehyde $(R)-1$ in 95:5 E/Z-selectivity and practically with no degradation of chiral integrity (Scheme 26) [89]. As an alternative, Lebel and Ladjel used a catalytic amount of $[\mathrm{Ir}(\mathrm{COD}) \mathrm{Cl}]_{2}$ for the in situ preparation of ylide $\mathbf{6 9}[114]$. They obtained a $81 \%$ yield in the reaction.<smiles>CCOC(=O)C=CC1COC(C)(C)N1C(=O)COC(C)=O</smiles>

Scheme 26: (a) Benzene, rt (82\%) [108]; (b) $\mathrm{K}_{2} \mathrm{CO}_{3}, \mathrm{MeOH}(85 \%)$ [89]; (c) iPrOH, [Ir(COD)Cl] $2, \mathrm{PPh}_{3}, \mathrm{THF}, \mathrm{rt}(81 \%)[114]$.

We have been interested in the synthesis of $Z$-enoate 73 [84]. The Still-Gennari modification to the phosphonate makes the synthesis of $Z$-enoates possible [115]. The two electron-withdrawing $\mathrm{CF}_{3} \mathrm{CH}_{2} \mathrm{O}$-groups destabilize the cis-oxaphosphetane intermediate (Scheme 27) and make the elimination reaction to the kinetic product $Z$-alkene a lot faster. As the elimination step becomes fast, the rate difference in the initial addition step between $k_{\text {anti }}$ and $k_{\text {syn }}$ determines the overall $Z$-selectivity. When the reaction was performed with $\mathrm{K}_{2} \mathrm{CO}_{3} / 18$-crown- 6 as the base in toluene at $-15{ }^{\circ} \mathrm{C}$, we could isolate only the $Z$-enoate $\mathbf{7 3}$ in good yield (90\%). HPLC analysis showed that there was no epimerization. 


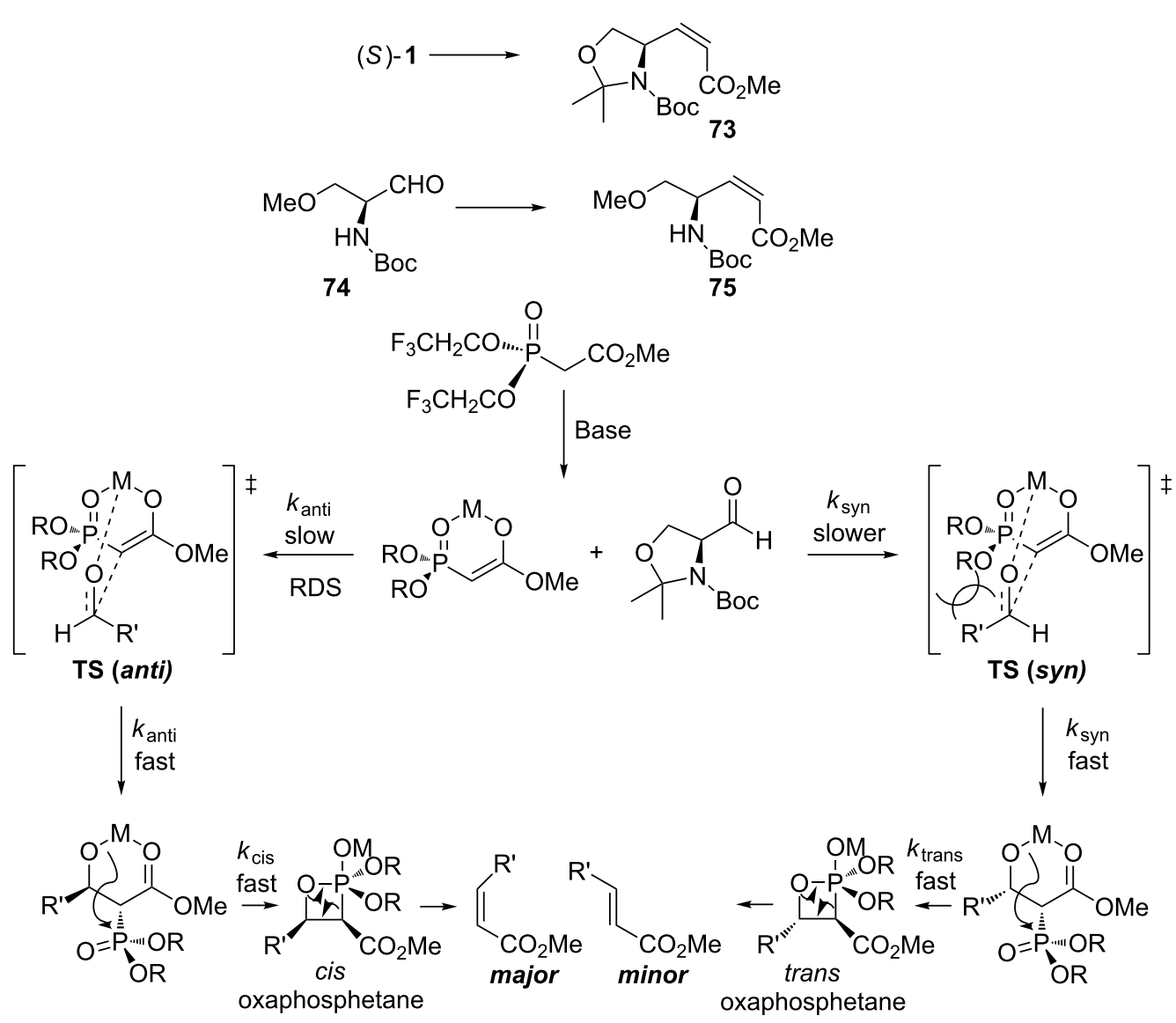

Scheme 27: Mechanism of the Still-Gennari modification of the HWE reaction leading to both olefin isomers.

We have recently shown that the open-chain aldehyde $\mathbf{7 4}$ reacts with the Still-Gennari phosphonate and provides the $Z$-enoate 75 in good $E / Z$-selectivity (1:12) [84]. The slight decrease in the $E / Z$-selectivity can be reasoned with the smaller size of the aldehyde $\mathbf{7 4}$. When the aldehyde is coordinating to the phosphonate, the steric hindrance caused by the interaction of the trifluoroethoxy group with the aldehyde R' in TS (syn) is smaller compared with aldehyde 1 . This allows some of the aldehyde to react via the trans-oxaphosphetane intermediate. Using these reaction conditions no epimerization was observed.

\section{Conclusion}

Garner's aldehyde has developed into a useful and reliable synthetic intermediate for the synthesis of enantiopure complex natural products, their analogues and other pharmacologically active compounds. Several reaction types have been studied sufficiently so that one has reliable tools to plan a synthesis. Simple addition reactions to the carbonyl group give access to vicinal amino alcohols, important building blocks for many natural products. Another possibility for carbon chain elongation are olefination reactions, which often lead to epimerization of the $\alpha$-stereocenter. As with the alkylations, strategies to avoid this undesired reaction have been developed. However, despite these important achievements, much more research needs to be done to increase the scopes of these reactions, the overall efficiency, and environmental sustainability.

\section{References}

1. Vallery-Radot, R.; Devonshire, R. L. Life of Pasteur (transl.); Dover Publications: New York, 1960; p 484.

2. Ramos Tombo, G. M.; Belluš, D. Angew. Chem., Int. Ed. Engl. 1991, 30, 1193-1215. doi:10.1002/anie.199111933

3. Lamberth, C. Tetrahedron 2010, 66, 7239-7256. doi:10.1016/j.tet.2010.06.008

4. Vaenkatesan, V.; Wegh, R. T.; Teunissen, J.-P.; Lub, J.; Bastiaansen, C. W. M.; Broer, D. J. Adv. Funct. Mater. 2005, 15 , 138-142. doi:10.1002/adfm.200400122

5. Zhuang, X. X.; Sun, X. X.; Li, L.; Li, Y. C. Adv. Mat. Res. 2011, 337, 151-154. doi:10.4028/www.scientific.net/AMR.337.151

6. Armstrong, R. W.; Beau, J. M.; Cheon, S. H.; Christ, W. J.; Fujioka, H.; Ham, W. H.; Hawkins, L. D.; Jin, H.; Kang, S. H.; Kishi, Y.; Martinelli, M. J.; McWhorter, W. W., Jr.; Mizuno, M.; Nakata, M.; Stutz, A. E.; Talamas, F. X.; Taniguchi, M.; Tino, J. A.; Ueda, K.; Uenishi, J.; White, J. B.; Yonaga, M. J. Am. Chem. Soc. 1989, 111, 7525-7530. doi:10.1021/ja00201a037 
7. Armstrong, R. W.; Beau, J. M.; Cheon, S. H.; Christ, W. J.; Fujioka, H.; Ham, W. H.; Hawkins, L. D.; Jin, H.; Kang, S. H.; Kishi, Y.; Martinelli, M. J.; McWhorter, W. W., Jr.; Mizuno, M.; Nakata, M.; Stutz, A. E.; Talamas, F. X.; Taniguchi, M.; Tino, J. A.; Ueda, K.; Uenishi, J.; White, J. B.; Yonaga, M. J. Am. Chem. Soc. 1989, 111, 7530-7533. doi:10.1021/ja00201a038

8. Suh, E. M.; Kishi, Y. J. Am. Chem. Soc. 1994, 116, 11205-11206. doi:10.1021/ja00103a065

9. Mangeney, P.; Andriamialisoa, R. Z.; Langlois, N.; Langlois, Y.; Potier, P. J. Am. Chem. Soc. 1979, 101, 2243-2245. doi:10.1021/ja00502a072

10. Kutney, J. P.; Choi, L. S. L.; Nakano, J.; Tsukamoto, H.; McHugh, M.; Boulet, C. A. Heterocycles 1988, 27, 1845-1853. doi:10.3987/COM-88-4611

11. Kuehne, M. E.; Matson, P. A.; Bornmann, W. G. J. Org. Chem. 1991, 56, 513-528. doi:10.1021/jo00002a008

12. Magnus, P.; Mendoza, J. S.; Stamford, A.; Ladlow, M.; Willis, P. J. Am. Chem. Soc. 1992, 114, 10232-10245. doi:10.1021/ja00052a020

13. Yokoshima, S.; Ueda, T.; Kobayashi, S.; Sato, A.; Kuboyama, T.; Tokuyama, H.; Fukuyama, T. J. Am. Chem. Soc. 2002, 124, 2137-2139. doi:10.1021/ja0177049

14. Ishikawa, H.; Colby, D. A.; Seto, S.; Va, P.; Tam, A.; Kakei, H.; Rayl, T. J.; Hwang, I.; Boger, D. L. J. Am. Chem. Soc. 2009, 131, 4904-4916. doi:10.1021/ja809842b

15. Nicolaou, K. C.; Yang, Z.; Liu, J. J.; Ueno, H.; Nantermet, P. G.; Guy, R. K.; Claiborne, C. F.; Renaud, J.; Couladouros, E. A.; Paulvannan, K.; Sorensen, E. J. Nature 1994, 367, 630-634. doi:10.1038/367630a0

16. Holton, R. A.; Somoza, C.; Kim, H. B.; Liang, F.; Biediger, R. J.; Boatman, P. D.; Shindo, M.; Smith, C. C.; Kim, S.; Nadizadeh, H.; Suzuki, Y.; Tao, C.; Vu, P.; Tang, S.; Zhang, P.; Murthi, K. K.; Gentile, L. N.; Liu, J. H. J. Am. Chem. Soc. 1994, 116, 1597-1598. doi:10.1021/ja00083a066

17. Holton, R. A.; Somoza, C.; Kim, H. B.; Liang, F.; Biediger, R. J.; Boatman, P. D.; Shindo, M.; Smith, C. C.; Kim, S.; Nadizadeh, H.; Suzuki, Y.; Tao, C.; Vu, P.; Tang, S.; Zhang, P.; Murthi, K. K.; Gentile, L. N.; Liu, J. H. J. Am. Chem. Soc. 1994, 116, 1599-1600. doi:10.1021/ja00083a067

18. Danishefsky, S. J.; Masters, J. J.; Young, W. B.; Link, J. T.; Snyder, L. B.; Magee, T. V.; Jung, D. K.; Isaacs, R. C. A.; Bornmann, W. G.; Alaimo, C. A.; Coburn, C. A.; Di Grandi, M. J. J. Am. Chem. Soc. 1996, 118, 2843-2859. doi:10.1021/ja952692a

19. Wender, P. A.; Badham, N. F.; Conway, S. P.; Floreancig, P. E.; Glass, T. E.; Gränicher, C.; Houze, J. B.; Jaenichen, J.; Lee, D.; Marquess, D. G.; McGrane, P. L.; Meng, W.; Mucciaro, T. P.; Mühlebach, M.; Natchus, M. G.; Paulsen, H.; Rawlins, D. B.; Satkofsky, J.; Shuker, A. J.; Sutton, J. C.; Taylor, R. E.; Tomooka, K. J. Am. Chem. Soc. 1997, 119, 2755-2756. doi:10.1021/ja9635387

20. Wender, P. A.; Badham, N. F.; Conway, S. P.; Floreancig, P. E.; Glass, T. E.; Houze, J. B.; Krauss, N. E.; Lee, D.; Marquess, D. G.; McGrane, P. L.; Meng, W.; Natchus, M. G.; Shuker, A. J.; Sutton, J. C.; Taylor, R. E. J. Am. Chem. Soc. 1997, 119, 2757-2758. doi:10.1021/ja963539z

21. Morihira, K.; Hara, R.; Kawahara, S.; Nishimori, T.; Nakamura, N.; Kusama, H.; Kuwajima, I. J. Am. Chem. Soc. 1998, 120, 12980-12981. doi:10.1021/ja9824932
22. Mukaiyama, T.; Shiina, I.; Iwadare, H.; Saitoh, M.; Nishimura, T.; Ohkawa, N.; Sakoh, H.; Nishimura, K.; Tani, Y.-I.; Hasegawa, M.; Yamada, K.; Saitoh, K. Chem.-Eur. J. 1999, 5, 121-161. doi:10.1002/(SICI)1521-3765(19990104)5:1<121::AID-CHEM121>3.3. $\mathrm{CO} ; 2-\mathrm{F}$

23. Doi, T.; Fuse, S.; Miyamoto, S.; Nakai, K.; Sasuga, D.; Takahashi, T. Chem.-Asian J. 2006, 1, 370-383. doi:10.1002/asia.200600156

24. Garner, P. Tetrahedron Lett. 1984, 25, 5855-5858. doi:10.1016/S0040-4039(01)81703-2

25. Garner, P.; Park, J. M. Org. Synth. 1990, 70, 18-28.

26. Garner, P.; Park, J. M. J. Org. Chem. 1987, 52, 2361-2364. doi:10.1021/jo00388a004

27. McKillop, A.; Taylor, R. J. K.; Watson, R. J.; Lewis, N. Synthesis 1994, 31-33. doi:10.1055/s-1994-25398

28. Dondoni, A.; Perroni, D. Org. Synth. 2000, 77, 64-77.

29. Roush, W. R.; Hunt, J. A. J. Org. Chem. 1995, 60, 798-806. doi:10.1021/j000109a008

30. Ocejo, M.; Vicario, J. L.; Badía, D.; Carrillo, L.; Reyes, E. Synlett 2005, 2110-2112. doi:10.1055/s-2005-871947

31. Jurczak, J.; Gryko, D.; Kobrzycka, E.; Gruza, H.; Prokopowicz, P. Tetrahedron 1998, 54, 6051-6064. doi:10.1016/S0040-4020(98)00299-3

32. Rauhala, V. Master's thesis, Department of Chemistry, University of Oulu, 1998, p. 87.

33. Clemens, A. J. L.; Burke, S. D. J. Org. Chem. 2012, 77, 2983-2985. doi:10.1021/jo300025t

34. Huntley, R. J.; Funk, R. L. Org. Lett. 2006, 8, 4775-4778. doi:10.1021/ol0617547

35. Chattopadhyay, S. K.; Sarkar, K.; Karmakar, S. Synlett 2005, 2083-2085. doi:10.1055/s-2005-871944

36. Bandyopadhyay, A.; Pal, B. K.; Chattopadhyay, S. K. Tetrahedron: Asymmetry 2008, 19, 1875-1877. doi:10.1016/j.tetasy.2008.07.032

37. Passiniemi, M.; Koskinen, A. M. P. Tetrahedron Lett. 2011, 52, 6736-6738. doi:10.1016/j.tetlet.2011.10.007

38. Garner, P.; Park, J. M. J. Org. Chem. 1990, 55, 3772-3787. doi:10.1021/jo00299a017

39. Takahata, H.; Banba, Y.; Ouchi, H.; Nemoto, H. Org. Lett. 2003, 5, 2527-2529. doi:10.1021/ol034886y

40. Takahata, H.; Banba, Y.; Sasatani, M.; Nemoto, H.; Kato, A.; Adachi, I. Tetrahedron 2004, 60, 8199-8205. doi:10.1016/j.tet.2004.06.112

41. Guaragna, A.; D’Errico, S.; D’Alonzo, D.; Pedatella, S.; Palumbo, G. Org. Lett. 2007, 9, 3473-3476. doi:10.1021/ol7014847

42. Guaragna, A.; D’Alonzo, D.; Paolella, C.; Palumbo, G. Tetrahedron Lett. 2009, 50, 2045-2047. doi:10.1016/j.tetlet.2009.02.111

43. Karjalainen, O. K.; Koskinen, A. M. P. Org. Biomol. Chem. 2011, 9 , 1231-1236. doi:10.1039/c0ob00747a

44. Garner, P.; Park, J. M.; Malecki, E. J. Org. Chem. 1988, 53, 4395-4398. doi:10.1021/jo00253a039

45. Soai, K.; Takahashi, K. J. Chem. Soc., Perkin Trans. 11994 , 1257-1258. doi:10.1039/P19940001257

46. Murakami, T.; Furusawa, K. Tetrahedron 2002, 58, 9257-9263. doi:10.1016/S0040-4020(02)01190-0

47. Murakami, T.; Furusawa, K.; Tamai, T.; Yoshikai, K.; Nishikawa, M. Bioorg. Med. Chem. Lett. 2005, 15, 1115-1119. doi:10.1016/j.bmcl.2004.12.010

48. Karjalainen, O. K.; Passiniemi, M.; Koskinen, A. M. P. Org. Lett. 2010, 12, 1145-1147. doi:10.1021/ol100037c 
49. Tamborini, L.; Conti, P.; Pinto, A.; Colleoni, S.; Gobbi, M.; De Micheli, C. Tetrahedron 2009, 65, 6083-6089. doi:10.1016/j.tet.2009.05.054

50. Lemke, A.; Büschleb, M.; Ducho, C. Tetrahedron 2010, 66, 208-214. doi:10.1016/j.tet.2009.10.102

51. Chisholm, J. D.; Van Vranken, D. L. J. Org. Chem. 2000, 65, 7541-7553. doi:10.1021/jo000911r

52. Liang, X.; Andersch, J.; Bols, M. J. Chem. Soc., Perkin Trans. 12001 , 2136-2157. doi:10.1039/B101054I

53. Karjalainen, O. K.; Koskinen, A. M. P. Org. Biomol. Chem. 2012, 10, 4311-4326. doi:10.1039/c2ob25357g

54. Reginato, G.; Meffre, P.; Gaggini, F. Amino Acids 2005, 29, 81-87. doi:10.1007/s00726-005-0184-y

55. Ahn, N. T. Top. Curr. Chem. 1980, 88, 146-162.

56. Cram, D. J.; Abd Elhafez, F. A. J. Am. Chem. Soc. 1952, 74, 5828-5835. doi:10.1021/ja01143a007

57. Reetz, M. T.; Hüllmann, M.; Seitz, T. Angew. Chem., Int. Ed. Engl. 1987, 26, 477-480. doi:10.1002/anie.198704771

58. Gruza, H.; Kiciak, K.; Krasiński, A.; Jurczak, J. Tetrahedron: Asymmetry 1997, 8, 2627-2631. doi:10.1016/S0957-4166(97)00306-6

59. Herold, P. Helv. Chim. Acta 1988, 71, 354-362. doi:10.1002/hlca.19880710208

60. Dale, J. A.; Dull, D. L.; Mosher, H. S. J. Org. Chem. 1969, 34, 2543-2549. doi:10.1021/jo01261a013

61. Coleman, R. S.; Carpenter, A. J. Tetrahedron Lett. 1992, 33, 1697-1700. doi:10.1016/S0040-4039(00)91709-X

62. Williams, L.; Zhang, Z.; Shao, F.; Carroll, P. J.; Joullié, M. M. Tetrahedron 1995, 52, 11673-11694. doi:10.1016/0040-4020(96)00672-2

63. Koskinen, A. M. P.; Hassila, H.; Myllymäki, V. T.; Rissanen, K. Tetrahedron Lett. 1995, 36, 5619-5622. doi:10.1016/0040-4039(95)01029-H

64. Marcus, Y. The Properties of Solvents; John Wiley \& Sons: Chichester, 1998; pp 142-160.

65. Fürstner, A.; Krause, H. Adv. Synth. Catal. 2001, 343, 343-350. doi:10.1002/1615-4169(20010430)343:4<343::AID-ADSC343>3.3.CO ;2-Q

66. Shimizu, M.; Wakioka, I.; Fujisawa, T. Tetrahedron Lett. 1997, 38, 6027-6030. doi:10.1016/S0040-4039(97)01340-3

67. Wong, L.; Tan, S. S. L.; Lam, Y.; Melendez, A. J. J. Med. Chem. 2009 , 52, 3618-3626. doi:10.1021/jm900121d

68. Mori, K.; Masuda, Y. Tetrahedron Lett. 2003, 44, 9197-9200. doi:10.1016/j.tetlet.2003.10.025

69. Chun, J.; Byun, H.-S.; Bittman, R. J. Org. Chem. 2003, 68, 348-354. doi:10.1021/jo026240+

70. Yadav, J. S.; Geetha, V.; Krishnam Raju, A.; Gnaneshwar, D.; Chandrasekhar, S. Tetrahedron Lett. 2003, 44, 2983-2985. doi:10.1016/S0040-4039(03)00390-3

71. Dhondi, P. K.; Carberry, P.; Choi, L. B.; Chisholm, J. D. J. Org. Chem. 2007, 72, 9590-9596. doi:10.1021/jo701643h

72. Zhang, X.; van der Donk, W. A. J. Am. Chem. Soc. 2007, 129, 2212-2213. doi:10.1021/ja067672v

73. Reginato, G.; Mordini, A.; Tenti, A.; Valacchi, M.; Broguiere, J. Tetrahedron: Asymmetry 2008, 19, 2882-2886. doi:10.1016/j.tetasy.2008.12.025

74. Hanessian, S.; Yang, G.; Rondeau, J.-M.; Neumann, U.; Betschart, C.; Tinelnot-Blomley, M. J. Med. Chem. 2006, 49, 4544-4567. doi:10.1021/jm060154a
75. Soai, K.; Ookawa, A.; Kaba, T.; Ogawa, K. J. Am. Chem. Soc. 1987, 109, 7111-7115. doi:10.1021/ja00257a034

76. Sa-ei, K.; Montgomery, J. Tetrahedron 2009, 65, 6707-6711. doi:10.1016/j.tet.2009.05.029

77. Suzuki, K.; Hasegawa, T.; Imai, T.; Maeta, H.; Ohba, S. Tetrahedron 1995, 51, 4483-4494. doi:10.1016/0040-4020(94)01135-M

78. Wipf, P.; Xu, W. Tetrahedron Lett. 1994, 35, 5197-5200. doi:10.1016/S0040-4039(00)77062-6

79. Wipf, P.; Jahn, H. Tetrahedron 1996, 52, 12853-12910. doi:10.1016/0040-4020(96)00754-5

80. Xu, C.; Negishi, E. Tetrahedron Lett. 1999, 40, 431-434. doi:10.1016/S0040-4039(98)02394-6

81. Passiniemi, M.; Koskinen, A. M. P. Tetrahedron Lett. 2008, 49, 980-983. doi:10.1016/j.tetlet.2007.12.014

82. Passiniemi, M.; Koskinen, A. M. P. Org. Biomol. Chem. 2011, 9 , 1774-1783. doi:10.1039/c0ob00643b

83. Koskinen, A. M. P.; Chen, Y. Tetrahedron Lett. 1991, 32, 6977-6980. doi:10.1016/0040-4039(91)80459-J

84. Passiniemi, M.; Koskinen, A. M. P. Synthesis 2010, 2816-2822. doi:10.1055/s-0029-1218843

85. Jeon, J.; Shin, M.; Yoo, J. W.; Oh, J. S.; Bae, J. G.; Jung, S. H.; Kim, Y. G. Tetrahedron Lett. 2007, 48, 1105-1108. doi:10.1016/j.tetlet.2006.12.084

86. Ribes, C.; Falomir, E.; Carda, M.; Marco, J. A. J. Org. Chem. 2008, 73, 7779-7782. doi:10.1021/j08012989

87. Mallesham, P.; Vijaykumar, B. V. D.; Shin, D.-S.; Chandrasekhar, S. Tetrahedron Lett. 2011, 52, 6145-6147. doi:10.1016/j.tetlet.2011.09.034

88. Jako, I.; Uiber, P.; Mann, A.; Taddei, M.; Wermuth, C. G. Tetrahedron Lett. 1990, 31, 1011-1014. doi:10.1016/S0040-4039(00)94416-2

89. Yoda, H.; Shirai, T.; Katagiri, T.; Takabe, K.; Kimata, K.; Hosoya, K. Chem. Lett. 1990, 2037-2038. doi:10.1246/cl.1990.2037

90. Hanessian, S.; Sumi, K. Synthesis 1991, 1083-1089. doi:10.1055/s-1991-28396

91. Hanessian, S.; Demont, E.; van Otterlo, W. A. L. Tetrahedron Lett 2000, 41, 4999-5003. doi:10.1016/S0040-4039(00)00765-6

92. Rastogi, S. K.; Kornienko, A. Tetrahedron: Asymmetry 2006, 17, 3170-3178. doi:10.1016/j.tetasy.2006.11.029

93. Jako, I.; Uiber, P.; Mann, A.; Wermuth, C.-G. J. Org. Chem. 1991, 56, 5729-5733. doi:10.1021/jo00019a055

94. Ranatunga, S.; Tang, C.-H. A.; Hu, C.-C. A.; Del Valle, J. R. J. Org. Chem. 2012, 77, 9859-9864. doi:10.1021/jo301723y

95. Sankar, K.; Rahman, H.; Das, P. P.; Bhimireddy, E.; Sridhar, B.; Mohapatra, D. K. Org. Lett. 2012, 14, 1082-1085. doi:10.1021/ol203466m

96. Wittig, G.; Schöllkopf, U. Chem. Ber. 1954, 87, 1318-1330. doi:10.1002/cber.19540870919

97. Wittig, G.; Haag, W. Chem. Ber. 1955, 88, 1654-1666. doi:10.1002/cber.19550881110

98. Horner, L.; Hoffmann, H.; Wippel, H. G. Chem. Ber. 1958, 91, 61-63. doi:10.1002/cber.19580910113

99. Horner, L.; Hoffmann, H.; Wippel, H. G.; Klahre, G. Chem. Ber. 1959, 92, 2499-2505. doi:10.1002/cber.19590921017

100.Wadsworth, W. S., Jr.; Emmons, W. D. J. Am. Chem. Soc. 1961, 83, 1733-1738. doi:10.1021/ja01468a042

101.Moriwake, T.; Hamano, S.; Saito, S.; Torii, S. Chem. Lett. 1987, 2085-2088. doi:10.1246/cl.1987.2085

102.Beaulieu, P. L.; Duceppe, J.-S.; Johnson, C. J. Org. Chem. 1991, 56, 4196-4204. doi:10.1021/jo00013a023 
103. Kolodiazhnyi, O. I. Phosphorus ylides - Chemistry and Application in Organic Synthesis; Wiley-VCH: Weinheim, Germany, 1999; pp 9-156. doi:10.1002/9783527613908.ch02

104.Oh, J. S.; Kim, B. H.; Kim, Y. G. Tetrahedron Lett. 2004, 45, 3925-3928. doi:10.1016/j.tetlet.2004.03.101

105.Schlosser, M.; Christmann, K. F. Angew. Chem., Int. Ed. Engl. 1966, 5, 126. doi:10.1002/anie.196601261

106.Drew, M. G. B.; Harrison, R. J.; Mann, J.; Tench, A. J.; Young, R. J. Tetrahedron 1999, 55, 1163-1172. doi:10.1016/S0040-4020(98)01094-1

107.Upadhyay, P. K.; Kumar, P. Synthesis 2010, 3063-3066. doi:10.1055/s-0030-1258185

108. Dondoni, A.; Merino, P.; Perrone, D. Tetrahedron 1993, 49 , 2939-2956. doi:10.1016/S0040-4020(01)80389-6

109.Bordwell, F. G. Acc. Chem. Res. 1988, 21, 456-463. doi:10.1021/ar00156a004

110.Pelšs, A.; Kumpulainen, E. T. T.; Koskinen, A. M. P. J. Org. Chem. 2009, 74, 7598-7601. doi:10.1021/jo9017588

111.Blanchette, M. A.; Choy, W.; Davis, J. T.; Essenfeld, A. P.; Masamune, S.; Roush, W. R.; Sakai, T. Tetrahedron Lett. 1984, 25, 2183-2186. doi:10.1016/S0040-4039(01)80205-7

112.Paterson, I.; Yeung, K.-S.; Smaill, J. B. Synlett 1993, 774-776. doi:10.1055/s-1993-22605

113. Blasdel, L. K.; Myers, A. G. Org. Lett. 2005, 7, 4281-4283. doi:10.1021/ol051785m

114. Lebel, H.; Ladjel, C. Organometallics 2008, 27, 2676-2678. doi:10.1021/om800255c

115.Still, W. C.; Gennari, C. Tetrahedron Lett. 1983, 24, 4405-4408. doi:10.1016/S0040-4039(00)85909-2

\section{License and Terms}

This is an Open Access article under the terms of the Creative Commons Attribution License (http://creativecommons.org/licenses/by/2.0), which permits unrestricted use, distribution, and reproduction in any medium, provided the original work is properly cited.

The license is subject to the Beilstein Journal of Organic Chemistry terms and conditions:

(http://www.beilstein-journals.org/bjoc)

The definitive version of this article is the electronic one which can be found at: doi:10.3762/bjoc. 9.300 